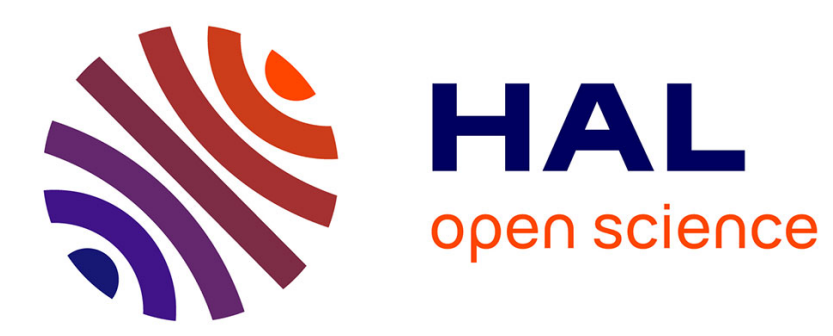

\title{
The Index of Economic Freedom: Methodological matters
}

\author{
Issaka Dialga, Thomas Vallée
}

\section{To cite this version:}

Issaka Dialga, Thomas Vallée. The Index of Economic Freedom: Methodological matters. 2015. hal-01178202

\section{HAL Id: hal-01178202 \\ https://hal.science/hal-01178202}

Preprint submitted on 17 Jul 2015

HAL is a multi-disciplinary open access archive for the deposit and dissemination of scientific research documents, whether they are published or not. The documents may come from teaching and research institutions in France or abroad, or from public or private research centers.
L'archive ouverte pluridisciplinaire HAL, est destinée au dépôt et à la diffusion de documents scientifiques de niveau recherche, publiés ou non, émanant des établissements d'enseignement et de recherche français ou étrangers, des laboratoires publics ou privés. 
EA 4272

\title{
The Index of Economic Freedom: Methodological matters
}

\author{
Issaka Dialga* \\ Thomas Vallée*
}

$2015 / 16$

$\left(^{*}\right)$ LEMNA, Université de Nantes

Laboratoire d'Economie et de Management Nantes-Atlantique Université de Nantes

Chemin de la Censive du Tertre - BP 52231 44322 Nantes cedex 3 - France

www.univ-nantes.fr/iemn-iae/recherche

Tél. +33 (0)2 40141717 - Fax +33 (0)2 40141749 


\title{
The Index of Economic Freedom: methodological matters
}

\author{
Issaka Dialga $^{1}$ and Thomas Vallée ${ }^{2}$ \\ LEMNA, University of Nantes, France
}

\begin{abstract}
Composite indicators (CIs) are essential in public debates and policies so the social demand for synthetic tools is constantly increasing. They are also subject to criticism (see Saisana and Saltelli 2010; Klugman et al, 2011) due to lack of a gold standard in their construction. The Index of Economic Freedom (IEF) is one of these tools subject to criticism because it suffers from methodological matters. The IEF lacks statistical validity because two of its components are strongly and negatively correlated with the others. Both components are causing significant variations in 95 percent of countries ranked. This paper deals with these issues by using Principal Components Analysis (PCA) and Benefit Of the Doubt (BOD) methods to generate component and country specific weights in computing the scores. The PCA and BOD analyses provide consistent results that differ dramatically with the baseline ones (results using equal weights). Given stable results provided by the PCA and BOD analysis, the IEF would receive broad legitimacy basing the calculation of its scores on endogenous weighting models.
\end{abstract}

Keywords: Index of economic freedom; Principal components Analysis; Benefit of the Doubt weighting system; country ranking

\footnotetext{
1issaka.dialga@etu.univ-nantes.fr

${ }^{2}$ Thomas.vallee@univ-nantes.fr
} 


\section{Introduction}

Composite indicators (CIs) are used in a wide range of fields such as the environment, the economy, society and technological development (OECD-JRC, 2008). CIs allow us to see "the big picture" and the complexity of a given sector, which cannot be captured by an individual indicator. It is an ideal means for comparing the performance of different countries. The United Nations Development Program (UNDP) has created many CIs such as the Human Development Index (HDI) which allows us to compare countries by taking into account the following dimensions: income, life expectancy and education. Nowadays, public policies are largely dependent on these synthetic tools. Hence, former French President, Mr. Nicolas Sarkozy, launched in 2008 a commission named "Commission on the Measurement of Economic Performance and Social Progress" or "Commission Sitglitz-Sen-Fitoussi". The social demand for such multidimensional measures has increased, like the political one as a consequence, and of course, research has increased as well (see Figure 2 in appendix 1).

Obviously, such indicators are not without their critics (Saisana and Saltelli, 2010; Klugman, et al, 2011). Most of these critics focus on the methodological aspects in the CIs construction. In particular, the choice of certain weights of variables as components in CIs can be very subjective with no empirical evidence nor defendable theoretical foundation presented (Conseil de l'Europe, 2005; Stiglitz, Sen and Fitoussi, 2009).

As a consequence, these critics persist in questioning the local legitimacy of these indicators as guidance and follow-up tools for public actions (FAIR, 2011) since they can send misleading policy messages if they are poorly constructed or misinterpreted (Saisana and Saltelli, 2010).

For the past two decades, the Heritage Foundation has published annually an index of economic freedom (IEF) in 186 countries all over the world. The index focuses on four aspects of the economic environment over which governments can exercise some policy control which can condemn individuals to poverty and deprivation (Heritage Foundation ,2014). Unfortunately, the index suffers from statistical validity. Two of its ten components are strongly and negatively correlated with the others meaning that all components are not necessarily equally weighted in the composite index (Nardo et al. 2005; OECD and JRC, 2008). 
This paper deals with this issue using PCA and BOD approach to generate unequal weights. The article is organized as follow: section 2 provides a short methodological description of the two problematical components of the index. We assess the contribution of two negative correlated components to countries ranking by removing them. Section 3 uses the two PCA and BOD methods to generate country specific score. Section 4 concludes by giving the salient points of the analysis.

\section{Index of Economic Freedom: methodological presentation}

According to the Heritage Foundation, most individuals lack economic freedom and opportunity because most of them are not free to work, produce, consume and invest in any way they please. Yet, economic freedom is one of the fundamental human rights. To assess the degree of a economically free society, the Heritage foundation constructed an index of economic freedom. The index focuses on four key aspects of economic activity over which governments can exercise some policy control. The four key domains are namely government size, market openness, regulatory efficiency and rule of law. The four aspects (pillars) are subdivided into 10 components (see Figure 1) that are aggregated using an arithmetic mean with equal weight. The index ranges from 0 to 100 with 100 the highest score. 


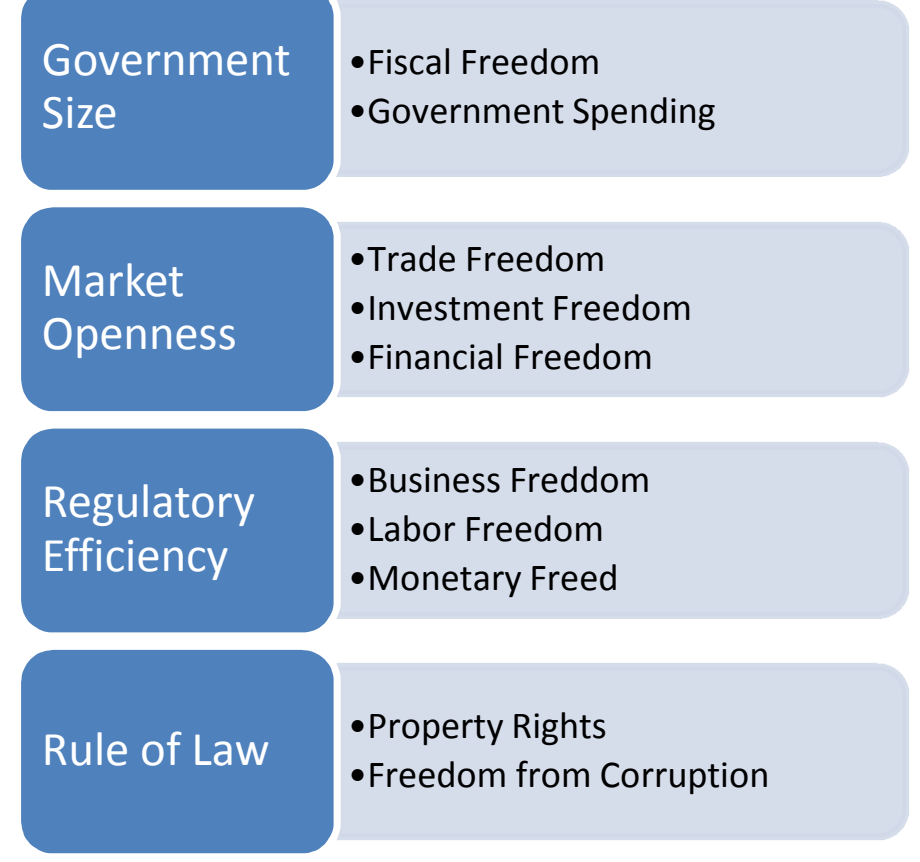

Figure 1 - The IEF framework

As recommended by Tarantola et Vertesy (2012), a multivariate analysis has to be carried out in order to verify the internal statistical consistency of the data within each pillar/dimension of the conceptual framework. Ideally, a composite indicator is structured in such a way that each pillar describes a single latent component. This requires a positive and high level of correlation within each pillar. There are two ways to test this: using a correlation table including all indicators and by conducting classical Principal Component Analysis (PCA) as a method of dimensionality. Based on the PCA results, relevant dimensions can be accepted if they adhere to the following criteria: (a) have an eigenvalue above 1 (Kaiser criterion); (b) account for at least $10 \%$ of total variance; (c) cumulatively contribute to more than $60 \%$ of total variance (OECD-JRC, 2008).

As we will see in Table 1, the "Government size" pillar is a problematic one. But first, let's explain exactly what it is. The components of the three other pillars are detailed in Appendix 2.

\section{Government size}

As illustrated in Figure 1, two indicators are used to take into account the influence of government control on economic freedom. They are fiscal freedom and government spending. 
Fiscal freedom measures the level of taxation of both individual and corporate income. The authors use a quadric cost function in the sub-indicator construction to reflect the diminishing revenue returns from very high rates of taxation. Formally, the index is:

$$
\text { Fiscal freedom }_{i j}=100-\alpha\left(\text { Factor }_{i j}\right)^{2}
$$

Where $j$ denotes three levels of taxation such as the top marginal tax rate on individual income, the top marginal tax rate on corporate income, and the total tax burden as a percentage of GDP; $i$ denotes the country. The $\alpha$ parameter is calibrated to 0.03 . Indeed, when there is no tax burden, the country gets the highest score which is equal to 100 .

Government spending captures the burden induced by government expenditures including state consumption and transfer payments. The idea is that government spending causes chronic budget deficits and the accumulation of public debt. Those are one of the most serious drags on economic dynamism. Methodologically, the authors use the same formula as fiscal freedom to construct scores:

$$
\text { Government Expenditures }_{i}=100-\alpha\left(\text { Expenditures }_{i}\right)^{2}
$$

Where $\alpha$ is scaled to 0.03 . The benchmark is zero expenditure while the optimal spending is assumed to be $30 \%$ of GDP. There is no theoretical justification for such a choice. Furthermore, if the government spending is greater or equal to $58 \%$ of GDP, the country score in this component is zero. In other words, $\alpha(30 \% \text { of GDP })^{2}$ provides an optimal score for the country $i$ while $100-\alpha(58 \% \text { of } G D P)^{2}=0$.

\section{Country ranking assessment without fiscal freedom and government spending components}

The two components have more impact on country ranking. As Table 8 shows in the appendix, removing the two components (fiscal freedom and government spending) causes large variations in country ranking. Considering 2014 IEF data, 95 per cent of countries change place. Most of them lose places ranging from one place (for Benin, Angola, and Singapore) to 23 (for Vanuatu). Countries such as France and Lesotho improve their scores and gain 43 and 50 places respectively. These preliminary results support our intuition that the two components deserve special attention. The section below deals with this matter. 


\section{Using PCA and BOD approaches for generating specific weights}

\subsection{PCA approach and correlation validity}

Once again, and following the recommendation of Tarantola and Vertesy (2012), each pillar should describe a single latent component which requires a positive and high level of correlation within each pillar and positive correlation inside each pillar. Furthermore, the question of weights is always an important one. Table 1 shows the correlation structure between the different components. As one can easily see, the two components, "Fiscal Freedom" and "Government Spending", which define the "Government Spending" pillar, are negatively correlated to the others. Such a negative correlation can be interpreted in two ways: first, the definition of the components is problematic; second, these components should belong to a separate pillar different from all the other components. We will not discuss whether or not these two components are theoretically well-defined, but we will concentrate on the second solution by conducting a PCA analysis. 
Table 1-Pearson Correlation Matrix

\begin{tabular}{|c|c|c|c|c|c|c|}
\hline & $\begin{array}{c}\text { PROPERTY } \\
\text { RIGHTS }\end{array}$ & $\begin{array}{c}\text { FREEDOM } \\
\text { FROM } \\
\text { CORRUPTION }\end{array}$ & $\begin{array}{c}\text { FISCAL } \\
\text { FREEDOM }\end{array}$ & $\begin{array}{c}\text { GOV'_T }^{\prime} \\
\text { SPENDING }\end{array}$ & $\begin{array}{l}\text { BUSINESS' } \\
\text { FREEDOM }\end{array}$ & $\begin{array}{c}\text { LABOR } \\
\text { FREEDOM }\end{array}$ \\
\hline $\begin{array}{l}\text { PROPERTY } \\
\text { RIGHTS }\end{array}$ & 1.000 & & & & & \\
\hline $\begin{array}{l}\text { FREEDOM FROM } \\
\text { CORRUPTION }\end{array}$ & 0.934 & 1.000 & & & & \\
\hline FISCAL FREEDOM & -0.211 & -0.240 & 1.000 & & & \\
\hline $\begin{array}{l}\text { GOV'_T } \\
\text { SPENDING }\end{array}$ & -0.317 & -0.371 & 0.476 & 1.000 & & \\
\hline $\begin{array}{l}\text { BUSINESS } \\
\text { FREEDOM }\end{array}$ & 0.702 & 0.680 & 0.077 & -0.209 & 1.000 & \\
\hline LABOR FREEDOM & 0.359 & 0.355 & 0.261 & -0.031 & 0.439 & 1.000 \\
\hline $\begin{array}{l}\text { MONETARY } \\
\text { FREEDOM }\end{array}$ & 0.479 & 0.432 & 0.193 & 0.037 & 0.474 & 0.303 \\
\hline TRADE FREEDOM & 0.505 & 0.489 & 0.128 & -0.130 & 0.577 & 0.313 \\
\hline $\begin{array}{l}\text { INVESTMENT } \\
\text { FREEDOM }\end{array}$ & 0.706 & 0.631 & -0.092 & -0.139 & 0.612 & 0.271 \\
\hline $\begin{array}{l}\text { FINANCIAL } \\
\text { FREEDOM }\end{array}$ & 0.746 & 0.670 & -0.020 & -0.134 & 0.644 & 0.278 \\
\hline
\end{tabular}

\section{Results of PCA Analysis}

PCA analysis highlights that at least two components exist. Notice that PCA supposed a linear arithmetic aggregation method. Methodologically, three conditions have to be satisfied. First, to determine the number of relevant latent variables in the set of components, the eigenvalue associated with the variable adopted should be $\geq 1$. Second, the individual contribution of the variable to the total variance should be at least $\geq 10 \%$. Third, the cumulative of variances must be $\geq 60 \%$.

Table 2: Determining the number of relevant factors

\begin{tabular}{|lccc|}
\hline Factors & Eigenvalues & \% of variance & Cumulative \% \\
\hline Factor 1 & $\mathbf{4 . 9 9 9}$ & $\mathbf{4 9 . 9 9 3}$ & $\mathbf{4 9 . 9 9 3}$ \\
\hline Factor 2 & $\mathbf{1 . 7 4 2}$ & $\mathbf{1 7 . 4 1 6}$ & $\mathbf{6 7 . 4 0 9}$ \\
\hline Factor 3 & 0.899 & 8.991 & 76.400 \\
\hline Factor 4 & 0.606 & 6.055 & 82.455 \\
\hline Factor 5 & 0.483 & 4.832 & 87.287 \\
\hline Factor 6 & 0.428 & 4.278 & 91.565 \\
\hline Factor 7 & 0.326 & 3.255 & 94.820 \\
\hline
\end{tabular}




\begin{tabular}{|llll|}
\hline Factor 8 & 0.287 & 2.872 & 97.692 \\
\hline Factor 9 & 0.174 & 1.744 & 99.436 \\
\hline Factor 10 & 0.056 & 0.564 & 100.00 \\
\hline
\end{tabular}

Table 2Table 2 shows that there are two relevant factors because only the first two factors meet the first condition of the choice of the number of latent factors (i.e. eigenvalues $\geq 1$ ). This result means that components belonging to each of those factors cannot be equally weighted as the Heritage Foundation has done. These results allowed us to use PCA method to generate countries specific weights.

Table 3: Components weights generated from PCA approach

\begin{tabular}{lcr}
\hline Variables & Weights & $\begin{array}{l}\text { Weights variation } \\
(\%)\end{array}$ \\
\hline \hline Property Rights & 0.115 & 15 \\
Freedom from Corruption & 0.103 & 3 \\
Fiscal Freedom & 0.124 & 23 \\
Gov't Spending & 0.095 & -5 \\
Business Freedom & 0.110 & 10 \\
Labor Freedom & 0.045 & -55 \\
Monetary Freedom & 0.084 & -16 \\
Trade Freedom & 0.094 & -6 \\
Investment Freedom & 0.113 & 13 \\
Financial Freedom & 0.119 & 19 \\
\hline
\end{tabular}

Table 3 shows, in contrast to the equal weight adopted by the Heritage Foundation, the specific component weight and its deviation (in \%) from the equal weight assumption. As one can see, although a small variation occurs concerning the Freedom from corruption indicator $(+3 \%)$, the change is substantial for the Labor Freedom indicator and the Fiscal Freedom one. This analysis can be done by looking at changes in the pillar level. As shown by Table 4, it impacts mainly the Regulatory Efficiency domain. The global weight of this key domain is reduced by $20 \%$, while all the other domains weight increase by approximately $8 \%$. 
Table 4- Evolution of the weights of the four key domains of the IEF

\begin{tabular}{|c|c|c|c|}
\hline \multicolumn{1}{|c|}{ Pillar } & IEF & PCA & Deviation (\%) \\
\hline Government size & 0.2 & 0.218 & +8.96 \\
\hline Market Openness & 0.3 & 0.326 & +8.70 \\
\hline Regulatory Efficiency & 0.3 & 0.238 & -20.56 \\
\hline Rule of Law & 0.3 & 0.218 & +8.83 \\
\hline
\end{tabular}

This result challenges the scores generated with the equal weighting method and consequently, the countries scorings and rankings. As one can note from Table 9, some important changes occur. At the extreme, the ranking of Morocco increases by 16, while the one of Tonga decreases by 9 . The ranking of the US decreases by 9 , moving from the $12^{\text {th }}$ position to the $21^{\text {st }}$ one. Indeed, as seen from Table 9 in the appendix, most of countries move from their initial positions (only $3 \%$ of countries retain their initial classification). The extent of the scores variation (compared to the baseline: equal weight) indicates that the equal weighting method adopted by the Heritage Foundation is a major methodological problem. Nevertheless, the positions of the first seven countries remain unchanged.

Table 5- Variation of the final ranking for some selected countries

\begin{tabular}{|c|c|c|c|}
\hline Country Name & IEF (2014) Ranking & PCA Ranking & Rank Variation \\
\hline Honduras & 112 & 96 & +16 \\
\hline Brazil & 114 & 106 & +9 \\
\hline South Korea & 31 & 23 & +8 \\
\hline Finland & 19 & 12 & +7 \\
\hline Tonga & 104 & 117 & -13 \\
\hline United States & 12 & 21 & -9 \\
\hline
\end{tabular}




\subsection{BOD approach}

The Benefit of the Doubt (BOD) approach allows weighting that is endogenously determined by the data in such a way that they are country specific. Furthermore, by looking at the values of those weights, it is possible to discuss whether or not the country has placed priorities in some specific dimensions of the index. The BOD method is based on the Data Envelopment Analysis (DEA) technique (Nardo et al. 2005; OECD-JRC 2008; DREES 2011).

Formally, one needs to solve the following maximization problem:

$$
C I_{s}=\max _{\left\{w_{s, i}\right\}_{i=1, \ldots, m}} \sum_{i=1}^{m} w_{s, i} y_{s, i}
$$

s.t. $\left\{\begin{array}{l}\sum_{i=1}^{m} w_{s, i} y_{\tilde{s}, i} \leq 1 \quad \tilde{s}=1, \ldots, k \\ w_{s, i} \geq 0 \quad i=1, \ldots, m\end{array}\right.$

with $\mathrm{k}$ the number of countries, and $\mathrm{m}$ the number of dimensions $\mathrm{m}=10$ in the IEFcase.

Table 6- Components specific weights and associate scores for selected countries

\begin{tabular}{|c|c|c|c|c|c|c|c|c|c|c|c|}
\hline $\begin{array}{l}\text { Country } \\
\text { Name }\end{array}$ & $\begin{array}{l}\text { Property } \\
\text { Rights }\end{array}$ & $\begin{array}{l}\text { Freedom } \\
\text { from } \\
\text { Corruption }\end{array}$ & $\begin{array}{l}\text { Fiscal } \\
\text { Freedom }\end{array}$ & $\begin{array}{c}\text { Gov't } \\
\text { Spending }\end{array}$ & $\begin{array}{l}\text { Business } \\
\text { Freedom }\end{array}$ & $\begin{array}{l}\text { Labor } \\
\text { Freedom }\end{array}$ & $\begin{array}{l}\text { Monetary } \\
\text { Freedom }\end{array}$ & $\begin{array}{l}\text { Trade } \\
\text { Freedom }\end{array}$ & $\begin{array}{l}\text { Investment } \\
\text { Freedom }\end{array}$ & $\begin{array}{l}\text { Financial } \\
\text { Freedom }\end{array}$ & score \\
\hline Honduras & 0.000 & 0.000 & 0187 & 0.406 & 0 & م000 & 0564 & 0000 & م0000 & חمח ח & 91 \\
\hline Brazil & 0.000 & 0.000 & 0.126 & 0.010 & 0.000 & 0.000 & 0.975 & 0.000 & 0.000 & 0.082 & 82 \\
\hline $\begin{array}{l}\text { South } \\
\text { Korea }\end{array}$ & 0.000 & 0.000 & 0.000 & 0.067 & 0.134 & 0.000 & 0.985 & 0.000 & 0.000 & 0.000 & 96 \\
\hline Finland & 0.642 & 0.054 & 0.011 & 0.000 & 0.057 & 0.000 & 0.000 & 0.000 & 0.346 & 0.000 & 100 \\
\hline Tonga & 0.000 & 0.000 & 0.386 & 0.000 & 0.000 & 0.672 & 0.000 & 0.000 & 0.000 & 0.000 & 95 \\
\hline $\begin{array}{l}\text { United } \\
\text { States }\end{array}$ & 0.062 & 0.000 & 0.000 & 0.000 & 0.000 & 0.979 & 0.000 & 0.000 & 0.000 & 0.000 & 100 \\
\hline $\begin{array}{l}\text { North } \\
\text { Korea }\end{array}$ & 0.000 & 1.000 & 0.000 & 0.000 & 0.000 & 0.000 & 0.000 & 0.000 & 0.000 & 0.000 & 5 \\
\hline China & 0.000 & 0.000 & 0.000 & 0.781 & 0.000 & 0.005 & 0.348 & 0.000 & 0.000 & 0.000 & 91 \\
\hline France & 0.000 & 0.000 & 0.000 & 0.000 & 0.000 & 0.000 & 0.000 & 1.000 & 0.000 & 0.000 & 92 \\
\hline Germany & 0.706 & 0.000 & 0.000 & 0.000 & 0.064 & 0.000 & 0.000 & 0.000 & 0.335 & 0.000 & 99 \\
\hline
\end{tabular}


Table 6 Table 6 presents various kinds of countries. These include the much more open countries such as the United States, and the protected ones like North Korea. The table shows that those heterogeneous countries have different policies according to their economy regulations. Furthermore, regulatory policies are different even within the same economic union. Indeed, if Germany focuses on several key variables (this diversification possibly explains its very high score of 99), France IEF is exclusively determined by only the trade freedom component. It is not surprising to notice the very low score for North Korea regarding its very little contact with the rest of the world. In the selected countries, only Finland's index components can be consider as well-balanced (five of the components in Finland's case received a weight different from zero), while the other countries have very specific priorities.

The complete results are presented in Table 10Table 11 in the appendix. The first one gives the specific component weights generated for each country. According to the BOD approach, Table 10 shows that all countries have very various priorities in terms of economic freedom. Most of them consider trade freedom as the first priority in the set of economic freedom components and this is followed by fiscal freedom in second place. Only Singapore constitutes a particular case: while the others concentrate all their efforts on the other dimensions of the index than property rights, Singapore has concentrated all its efforts on property rights (the weight in this component equals 1 which implies that weights of the nine remaining components equal zero). It is also important to note that no country gives equal importance to the ten components of the index as was supposed by the Heritage Foundation.

Table 7- Equal, PCA and BOD weights variation

\begin{tabular}{|c|c|c|c|c|c|c|}
\hline & Equal & PCA & $\mathrm{BOD}^{3}$ & $\begin{array}{l}\text { Deviation (\%) } \\
\text { between PCA } \\
\text { and Equal }\end{array}$ & $\begin{array}{c}\text { Deviation } \\
(\%) \text { between } \\
\text { PCA and BOD }\end{array}$ & $\begin{array}{c}\text { Deviation } \\
(\%) \text { between } \\
\text { PCA and BOD }\end{array}$ \\
\hline $\begin{array}{l}\text { PROPERTY } \\
\text { RIGHTS }\end{array}$ & 0.1 & 0.115 & 0.059 & 15 & -41 & 48 \\
\hline $\begin{array}{l}\text { FREEDOM } \\
\text { FROM } \\
\text { CORRUPTION }\end{array}$ & 0.1 & 0.103 & 0.008 & 3 & -92 & 92 \\
\hline $\begin{array}{l}\text { FISCAL } \\
\text { FREEDOM }\end{array}$ & 0.1 & 0.124 & 0.160 & 23 & 60 & -29 \\
\hline $\begin{array}{l}\text { GOV_T } \\
\text { SPENDING }\end{array}$ & 0.1 & 0.095 & 0.190 & -5 & 90 & -100 \\
\hline $\begin{array}{l}\text { BUSINESS } \\
\text { FREEDOM }\end{array}$ & 0.1 & 0.110 & 0.010 & 10 & -89 & 90 \\
\hline
\end{tabular}

\footnotetext{
${ }^{3}$ The summary weights are the overall of countries specific weights.
} 


\begin{tabular}{|l|r|r|r|r|r|r|}
\hline $\begin{array}{l}\text { LABOR } \\
\text { FREEDOM }\end{array}$ & 0.1 & 0.045 & 0.028 & -55 & -71 & 37 \\
\hline $\begin{array}{l}\text { MONETARY } \\
\text { FREEDOM }\end{array}$ & 0.1 & 0.084 & 0.263 & -16 & 164 & -214 \\
\hline $\begin{array}{l}\text { TRADE } \\
\text { FREEDOM }\end{array}$ & 0.1 & 0.094 & 0.254 & -6 & 154 & -170 \\
\hline $\begin{array}{l}\text { INVESTMENT } \\
\text { FREEDOM }\end{array}$ & 0.1 & 0.113 & 0.024 & 13 & -76 & 78 \\
\hline $\begin{array}{l}\text { FINANCIAL } \\
\text { FREEDOM }\end{array}$ & 0.1 & 0.119 & 0.059 & 19 & -41 & 48 \\
\hline
\end{tabular}

Results of Table 11 confirm that using the equal weighting method to generate countries scores in the case of the IEF is an inappropriate approach. The country specific approach (BOD) reveals that countries do not have the same policies in terms of economic freedom and so, components of this index must be weighted differently. Doing so, one can observe that the method favors certain countries (53\% of countries) while $47 \%$ of them saw their scores decreased. The contrast of those results (weights variation between the three methods used in this paper are very important, see Table 7Table 7) reinforces the necessity to justify the methodological approach adopted by a coherent theoretical framework.

\section{Conclusion}

The aim of this paper was to highlight the methodological problem of the choice of equal weighting in the Index of Economic Freedom. The principal components analysis found broad agreement that there are two distinct latent components in the index suggesting different weights of the components. Using the PCA method, countries scores and rankings are dramatically changed as compared to the baseline. The Benefit Of the Doubt method used secondly confirms the necessity to adopt a country specific weighting method in the case of the IEF. The contrast of those results reinforces the necessity to justify the methodological approach adopted by a coherent theoretical framework. Using statistical tools such as PCA or adopting a country specific weighting method like BOD seem to be a more legitimate approach than the simple equal weighting method. In order to keep its legitimacy, the Heritage Foundation should adopt one of the approaches developed in this paper, as our results have questioned the annual publications of this institute. 


\section{References}

Conseil de l'Europe. 2005. Elaboration concertée des indicateurs de la cohésion sociale: guide méthodologique. Council of Europe.

DREES. 2011. «Analyse critique du développement d'indicateurs composites : le cas de l'infarctus du myocarde après la phase aiguë ». http://www.drees.sante.gouv.fr/analyse-critique-dudeveloppement-d-indicateurs-composites-le-cas-de-l-infarctus-du-myocarde-apres-la-phaseaigue, $8500 . \mathrm{html}$.

FAIR. 2011. «La richesse autrement, un « riche» hors série». http://www.alternativeseconomiques.fr/la-richesse-autrement_fr_pub_1071.html.

Heritage Foundation. 2014. «2014 Index of Economic Freedom », Think Tank Edition. http://www.heritage.org/index/about.

Klugman, Jeni, Francisco Rodríguez, et Hyung-Jin Choi. 2011. «The HDI 2010: New Controversies, Old Critiques ». The Journal of Economic Inequality 9 (2): 249088. doi:10.1007/s10888-0119178-z.

Nardo, Michela, Michaela Saisana, Andrea Saltelli, et Stefano Tarantola. 2005. « Tools for Composite Indicators Building ». In European Commission, EUR 21682 EN, Institute for the Protection and Security of the Citizen, JRC Ispra, Italy, 131.

OECD-JRC. 2008. Handbook on Constructing Composite Indicators: Methodology and User Guide. OECD Publishing. http://www.keepeek.com/Digital-Asset-

Management/oecd/economics/handbook-on-constructing-composite-indicators-methodologyand-user-guide_9789264043466-en\#page1.

Saisana, Michaela, et Andrea Saltelli. 2010. Uncertainty and sensitivity analysis of the 2010 environmental performance index. OPOCE. http://www.yale.edu/epi/files/2008EPI_SensitivityAnalysis.pdf.

Stiglitz, Joseph, Amartya Sen, et Jean-Paul Fitoussi. 2009. «Report of the Commission on the Measurement of Economic performance and Social Progress ». http://www.stiglitz-senfitoussi.fr/documents/rapport_anglais.pdf.

Tarantola, Stefano, et Daniel Vertesy. 2012. «Composite Indicators of Research Excellence ». EUR Scientific and Technical Research Reports, Institute for the Protection and Security of the Citizen. 


\section{Appendix}

\section{Appendix 1: Evolution of the use of Cis for research purpose.}
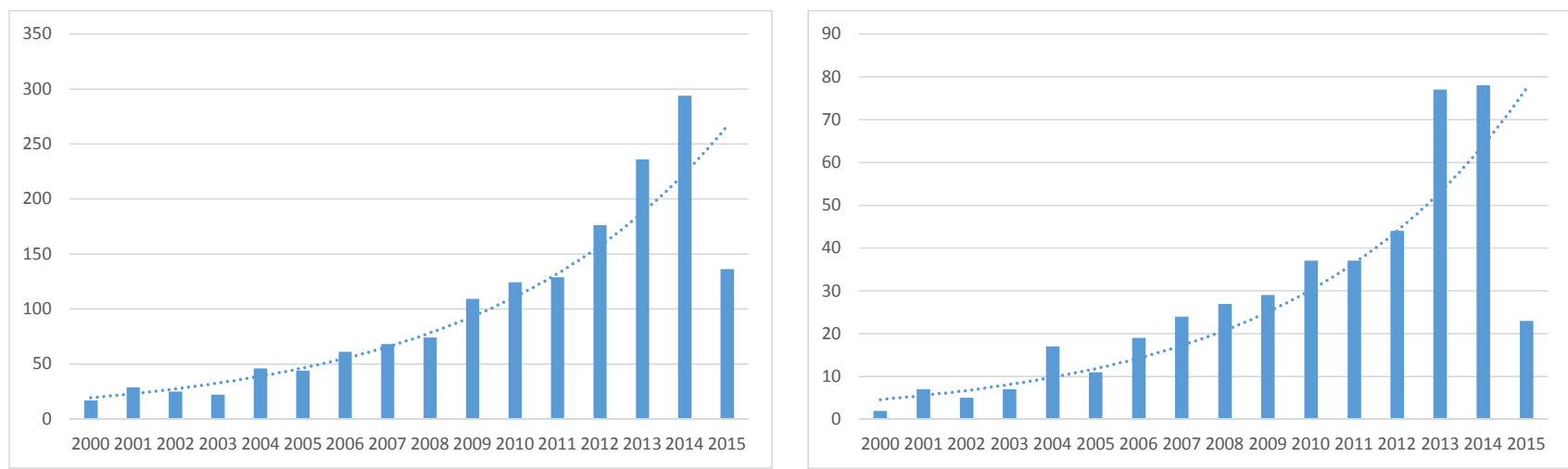

Figure 2 - Evolution of the number of research articles on "Composite Indicators" published in ScienceDirect between 2000 and 2015 (18/03) in all journals (left side) and in Economics, Econometrics and Finance journals (right side)

\section{Appendix 2: The eight other components of the IEF}

\section{Rule of Law}

Two components are used to assess this aspect: property rights and freedom from corruption. The properties rights are used to capture private accumulated property and its protection. The more effective protection of property is balanced with a higher score. The authors use a categorical scheme to allocate the scores within countries. The idea behind freedom of corruption is that corruption erodes economic freedom by introducing insecurity and uncertainty. It also reduces economic vitality by increasing costs and shifting resources into unproductive activities (Heritage Foundation, 2014). The score of this component derives from Transparency International's Corruption Index (CPI) following this formula: Corruption ${ }_{x i}=$ $(10-C P I) /(10-95) \times 100$ where 10 and 95 are respectively upper and lower bounds. According to 2012 review methodology, the higher value of CPI is to assign very little corruption. 


\section{Regulatory efficiency}

Three components are used here: business freedom, labor freedom and monetary freedom. Business freedom captures the ease of starting, operating and closing a business using ten World Bank "doing business" indicators. Each index of the sub-indicator is scaled from zero to 100 using the following formula:Facor score s $_{i}=50 \times$ Facor $_{\text {average }} /$ Factor $_{i}$ where Facor $_{\text {average }}$ is the overall score of the 187 countries.

Labor freedom assesses the regulation of the country labor market such as the existence of minimum wage, laws inhibiting layoffs, severance requirements and measurable regulatory restraints on hiring and hours worked. The authors use the same formula as this described above.

Facor score s $_{i}=50 \times$ Facor $_{\text {average }} /$ Factor $_{i}$ where $i$ denotes the six following factors: ratio of minimum wage to the average value added per worker, hindrance to hiring additional workers, rigidity of hours, difficulty of firing redundant employees, a legally mandated notice period, and mandatory severance pay. The labor freedom index is the simple average score of the six factors weighted equally.

The monetary freedom component combines price stability and price control. The authors assume that both inflation and price control distort market activity. Price stability without microeconomic intervention (on the country level) is the ideal state for a free market (Heritage Foundation, 2014). The monetary freedom index is constructed as follows:

Monetary freedom $_{i}=100-\alpha\left(\text { weighted }_{\text {avg. }} \text { inflation }- \text { Price control penalty }\right)^{1 / 2} \quad$ with weighted $_{\text {avg. }}$ inflation the inflation rates of the past three years taken on average;Price control penalty ranging from zero to 20 where 20 is assigned as a severe penalty due to price control. The $\alpha$ parameter represents a coefficient that stabilizes the variance of scores. It is assumed to be 6.333 .

\section{Market openness}

The remaining three components namely trade freedom, investment freedom and financial freedom are grouped in this last aspect. Trade freedom is the measure of the extent that tariffs 
and non-tariffs impact goods and services trade. The trade freedom sub-indicator is normalized as follows:

Trade Freedom $_{i}=\left[\left(\left(\right.\right.\right.$ Tariff $\left._{\max }-\operatorname{tariff}_{i}\right) /\left(\right.$ Tariff $\left.\left.\left._{\text {max }}-\operatorname{tariff}_{\min }\right)\right) \times 100-N T B_{i}\right] \quad$ where $N T B_{i}$ denotes Non-Tariff Barriers penalty ranges from zero to 20 .

Both investment freedom and financial freedom components use a categorial scheme to assign countries scores. The investment freedom scheme ranges from 0 (no national treatment, prescreening or expropriation with no legal recourse) to 100 (most transfers approved with some restrictions or one or two sectors restricted). The same scheme is used to scale the financial freedom sub-indicator score with 0 if the government uses repression and 100 if there is negligible government interference.

Table 8: Country ranking assessment without fiscal freedom and government spending components

\begin{tabular}{lrrr}
\hline Country & & & Rank \\
\hline Albania & score & Rank & variation \\
Algeria & 62.6 & 67 & -13 \\
Angola & 47.1 & 138 & 8 \\
Argentina & 41.7 & 161 & -1 \\
Armenia & 41.5 & 163 & 3 \\
Australia & 65.1 & 55 & -14 \\
Austria & 86.7 & 5 & -2 \\
Azerbaijan & 81.2 & 13 & 11 \\
Bahamas & 57.5 & 85 & -4 \\
Bahrain & 64.5 & 59 & -23 \\
Bangladesh & 72.5 & 28 & -15 \\
Barbados & 47.0 & 140 & -9 \\
Belarus & 69.9 & 37 & 8 \\
Belgium & 43.9 & 153 & -3 \\
Belize & 79.9 & 15 & 20 \\
Benin & 51.4 & 121 & -6 \\
Bhutan & 52.1 & 114 & -1 \\
Bolivia & 53.4 & 105 & 11 \\
Bosnia and Herzegovina & 41.8 & 160 & -2 \\
Botswana & 59.2 & 76 & 25 \\
Brazil & 71.2 & 31 & -4 \\
Bulgaria & 55.7 & 91 & 23 \\
Burkina Faso & 62.7 & 65 & -4 \\
Burma & 53.0 & 107 & -9 \\
Burundi & 36.1 & 170 & -8 \\
& 48.6 & 131 & 10
\end{tabular}




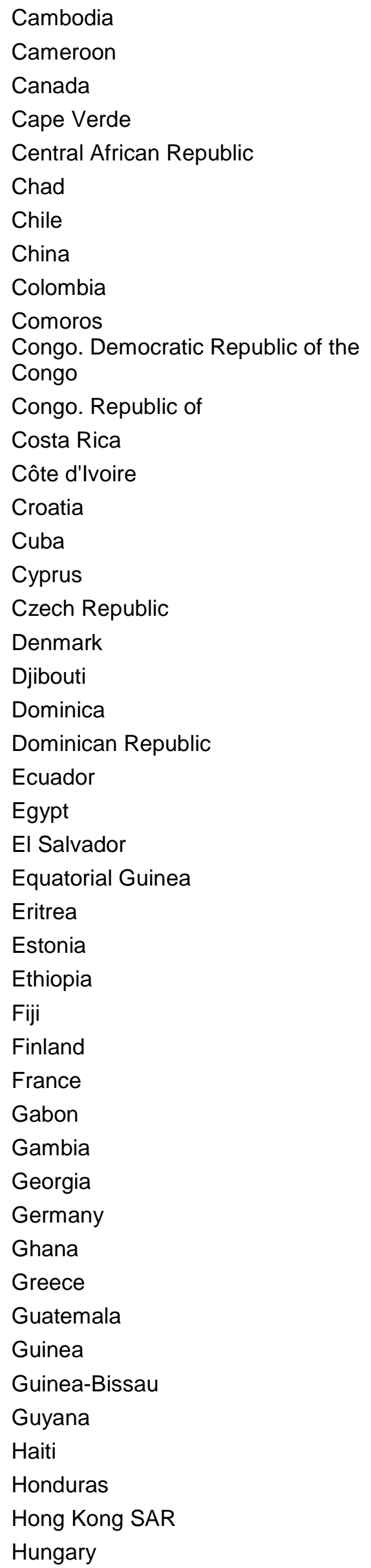

$\begin{array}{lll}49.3 & 129 & -21\end{array}$

$\begin{array}{lll}46.1 & 148 & -12\end{array}$

$\begin{array}{lll}84.3 & 7 & -1\end{array}$

$64.4 \quad 60 \quad 0$

$38.7 \quad 166 \quad-5$

$39.9 \quad 165 \quad 2$

$\begin{array}{lll}78.4 & 18 & -11\end{array}$

$\begin{array}{lll}46.5 & 145 & -8\end{array}$

$68.9 \quad 39 \quad-5$

$45.5 \quad 150 \quad-8$

$\begin{array}{lll}32.8 & 171 & 1\end{array}$

$36.3169 \quad 0$

$\begin{array}{lll}62.4 & 68 & -15\end{array}$

$\begin{array}{lll}52.3 & 113 & -6\end{array}$

$61.1 \quad 71 \quad 16$

$28.4 \quad 177 \quad 0$

$\begin{array}{lll}70.1 & 36 & 10\end{array}$

$\begin{array}{lll}74.6 & 23 & 3\end{array}$

$90.1 \quad 1 \quad 9$

$\begin{array}{lll}52.0 & 117 & 1\end{array}$

$\begin{array}{lll}64.7 & 58 & 5\end{array}$

$54.6 \quad 93 \quad-13$

$\begin{array}{lll}44.8 & 152 & 7\end{array}$

$\begin{array}{lll}46.7 & 142 & -7\end{array}$

$\begin{array}{lll}62.0 & 69 & -10\end{array}$

$\begin{array}{lll}38.2 & 167 & 1\end{array}$

$\begin{array}{lll}32.7 & 172 & 2\end{array}$

$\begin{array}{lll}77.8 & 19 & -8\end{array}$

$\begin{array}{lll}41.6 & 162 & -11\end{array}$

$\begin{array}{lll}53.6 & 103 & -4\end{array}$

$\begin{array}{lll}82.5 & 11 & 8\end{array}$

$\begin{array}{lll}72.6 & 27 & 43\end{array}$

$\begin{array}{lll}52.8 & 109 & -4\end{array}$

$54.5 \quad 94 \quad-2$

$\begin{array}{lll}71.1 & 32 & -10\end{array}$

$79.4 \quad 16 \quad 2$

$59.2 \quad 75 \quad-9$

$59.0 \quad 78 \quad 41$

$\begin{array}{lll}54.8 & 92 & -9\end{array}$

$47.5 \quad 136 \quad-3$

$42.2 \quad 159 \quad-16$

$\begin{array}{lll}52.0 & 115 & 6\end{array}$

$42.8 \quad 156 \quad 0$

$\begin{array}{lll}50.8 & 123 & -11\end{array}$

$89.8 \quad 2 \quad-1$

$\begin{array}{lll}70.3 & 35 & 16\end{array}$ 


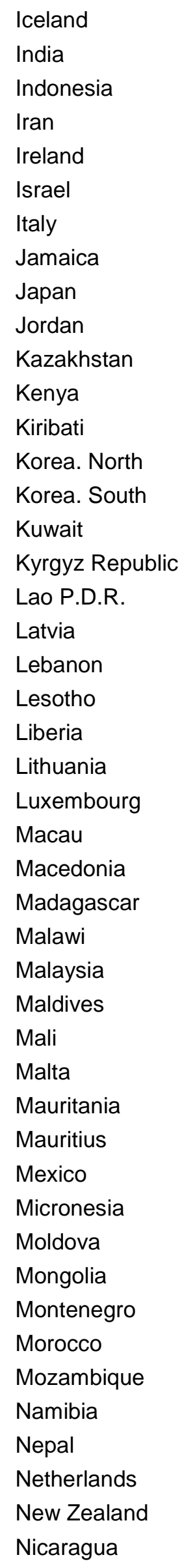

$77.3 \quad 20 \quad 3$

$49.9 \quad 126 \quad-6$

$51.5 \quad 120 \quad-20$

$29.5 \quad 173 \quad 0$

$82.2 \quad 12 \quad-3$

$\begin{array}{lll}73.0 & 25 & 19\end{array}$

$66.0 \quad 51 \quad 35$

$65.1 \quad 56 \quad 0$

$\begin{array}{lll}75.9 & 22 & 3\end{array}$

$66.4 \quad 49 \quad-10$

$\begin{array}{lll}57.4 & 87 & -20\end{array}$

$52.3 \quad 112 \quad-1$

$48.9 \quad 130 \quad 34$

$1.3178 \quad 0$

$70.9 \quad 34 \quad-3$

$58.7 \quad 81 \quad-5$

$57.0 \quad 88 \quad-3$

$42.3158 \quad-14$

$68.4 \quad 44 \quad-2$

$53.6101 \quad-5$

$53.4104 \quad 50$

$46.3 \quad 146 \quad-8$

$72.6 \quad 26 \quad-5$

$78.9 \quad 17 \quad-1$

$68.7 \quad 41 \quad-12$

$65.5 \quad 53 \quad-10$

$54.3 \quad 97 \quad-18$

$51.6 \quad 119 \quad 5$

$67.0 \quad 47 \quad-10$

$46.2147 \quad-2$

$50.5 \quad 124 \quad-2$

$69.2 \quad 38 \quad 20$

$46.8 \quad 141 \quad-7$

$73.9 \quad 24 \quad-16$

$63.5 \quad 62 \quad-7$

$50.1 \quad 125 \quad 28$

$54.1 \quad 99 \quad 11$

$58.5 \quad 83 \quad 14$

$\begin{array}{lll}62.6 & 66 & 2\end{array}$

$56.0 \quad 90 \quad 13$

$51.2 \quad 122 \quad 6$

$58.6 \quad 82 \quad 12$

$40.7 \quad 164 \quad-15$

83.1996

$88.5 \quad 4 \quad 1$

$53.2106 \quad-4$ 


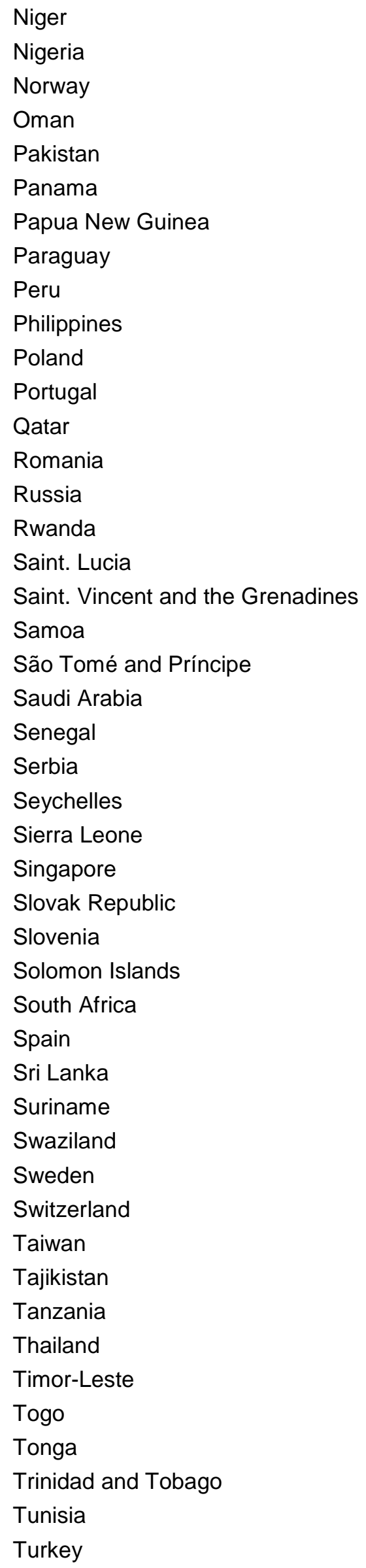

$\begin{array}{lll}48.2 & 133 & -6\end{array}$

$\begin{array}{lll}48.0 & 134 & -5\end{array}$

$77.0 \quad 21 \quad 11$

$64.9 \quad 57 \quad-9$

$\begin{array}{lll}47.8 & 135 & -9\end{array}$

$\begin{array}{lll}58.8 & 79 & -8\end{array}$

$\begin{array}{lll}49.6 & 127 & 5\end{array}$

$54.3 \quad 96 \quad-18$

$\begin{array}{lll}63.3 & 64 & -17\end{array}$

$\begin{array}{lll}53.6 & 100 & -11\end{array}$

$68.9 \quad 40 \quad 10$

$68.5 \quad 43 \quad 26$

$67.5 \quad 46 \quad-16$

$\begin{array}{lll}63.6 & 61 & 1\end{array}$

$\begin{array}{lll}46.5 & 144 & -4\end{array}$

$\begin{array}{lll}61.0 & 72 & -7\end{array}$

$71.0 \quad 33 \quad 0$

$65.4 \quad 54 \quad-2$

$\begin{array}{lll}61.1 & 70 & 14\end{array}$

$\begin{array}{lll}46.7 & 143 & 14\end{array}$

$57.4 \quad 86 \quad-9$

$\begin{array}{lll}51.7 & 118 & 7\end{array}$

$\begin{array}{lll}59.0 & 77 & 18\end{array}$

$52.9 \quad 108 \quad 9$

$42.4 \quad 157 \quad-9$

$89.0 \quad 3 \quad-1$

$66.0 \quad 52 \quad 5$

$\begin{array}{lll}68.2 & 45 & 29\end{array}$

$\begin{array}{lll}47.4 & 137 & 28\end{array}$

$\begin{array}{lll}60.9 & 73 & 2\end{array}$

$72.5 \quad 29 \quad 20$

$\begin{array}{lll}53.6 & 102 & -12\end{array}$

$\begin{array}{lll}49.3 & 128 & 2\end{array}$

$58.3 \quad 84 \quad-2$

$83.3 \quad 8 \quad 12$

$\begin{array}{lll}85.1 & 6 & -2\end{array}$

$\begin{array}{lll}71.8 & 30 & -13\end{array}$

$\begin{array}{lll}43.6 & 154 & -15\end{array}$

$\begin{array}{lll}52.5 & 111 & -5\end{array}$

$58.8 \quad 80 \quad-8$

$46.0 \quad 149 \quad 21$

$43.4 \quad 155 \quad-3$

$52.5 \quad 110 \quad-6$

$\begin{array}{lll}60.0 & 74 & -1\end{array}$

$54.4 \quad 95 \quad 14$

$\begin{array}{lll}63.4 & 63 & 1\end{array}$ 


\begin{tabular}{lrrr} 
Turkmenistan & 29.2 & 175 & -4 \\
Uganda & 54.1 & 98 & -7 \\
Ukraine & 47.1 & 139 & 16 \\
United Arab Emirates & 66.4 & 50 & -22 \\
United Kingdom & 82.9 & 10 & 4 \\
United States & 80.1 & 14 & -2 \\
Uruguay & 68.5 & 42 & -4 \\
Uzbekistan & 38.0 & 168 & -5 \\
Vanuatu & 52.0 & 116 & -23 \\
Venezuela & 29.5 & 174 & 1 \\
Vietnam & 44.9 & 151 & -4 \\
Yemen & 48.5 & 132 & -9 \\
Zambia & 56.1 & 89 & -1 \\
Zimbabwe & 28.5 & 176 & 0 \\
Brunei Darussalam & 66.8 & 48 & -8 \\
\hline
\end{tabular}

Table 9: scores and ranking variations between Equal and PCA weighting

\begin{tabular}{|c|c|c|c|c|c|}
\hline Country Name & $\begin{array}{l}2014 \\
\text { Score }\end{array}$ & Ranking & $\begin{array}{c}\text { score } \\
\text { with PCA } \\
\text { weighting }\end{array}$ & $\begin{array}{c}\text { New } \\
\text { Ranking }\end{array}$ & $\begin{array}{c}\text { Rank } \\
\text { variation }\end{array}$ \\
\hline Albania & 66.9 & 54 & 67.8 & 45 & 9 \\
\hline Algeria & 50.8 & 146 & 50.7 & 141 & 5 \\
\hline Angola & 47.7 & 160 & 47.9 & 158 & 2 \\
\hline Argentina & 44.6 & 166 & 43.8 & 164 & 2 \\
\hline Armenia & 68.9 & 41 & 68.0 & 42 & -1 \\
\hline Australia & 82.0 & 3 & 82.3 & 3 & 0 \\
\hline Austria & 72.4 & 24 & 72.0 & 26 & -2 \\
\hline Azerbaijan & 61.3 & 81 & 59.9 & 86 & -5 \\
\hline Bahamas & 69.8 & 36 & 69.2 & 36 & 0 \\
\hline Bahrain & 75.1 & 13 & 75.1 & 17 & -4 \\
\hline
\end{tabular}




\begin{tabular}{|c|c|c|c|c|c|}
\hline Bangladesh & 54.1 & 131 & 53.4 & 129 & 2 \\
\hline Barbados & 68.3 & 45 & 67.8 & 44 & 1 \\
\hline Belarus & 50.1 & 150 & 48.4 & 156 & -6 \\
\hline Belgium & 69.9 & 35 & 69.7 & 34 & 1 \\
\hline Belize & 56.7 & 115 & 55.6 & 115 & 0 \\
\hline Benin & 57.1 & 113 & 56.8 & 111 & 2 \\
\hline Bhutan & 56.7 & 116 & 54.8 & 124 & -8 \\
\hline Bolivia & 48.4 & 158 & 48.8 & 151 & 7 \\
\hline Bosnia and Herzegovina & 58.4 & 101 & 58.1 & 100 & 1 \\
\hline Botswana & 72.0 & 27 & 72.2 & 24 & 3 \\
\hline Brazil & 56.9 & 114 & 57.1 & 106 & 8 \\
\hline Bulgaria & 65.7 & 61 & 64.5 & 66 & -5 \\
\hline Burkina Faso & 58.9 & 98 & 58.4 & 98 & 0 \\
\hline Burma & 46.5 & 162 & 43.4 & 167 & -5 \\
\hline Burundi & 51.4 & 141 & 50.2 & 143 & -2 \\
\hline Cambodia & 57.4 & 108 & 57.2 & 105 & 3 \\
\hline Cameroon & 52.6 & 136 & 51.7 & 135 & 1 \\
\hline Canada & 80.2 & 6 & 80.4 & 6 & 0 \\
\hline Cape Verde & 66.1 & 60 & 67.1 & 53 & 7 \\
\hline
\end{tabular}


Central African Republic

Chad

Chile

China

Colombia

Comoros

Congo. Democratic Republic of the Congo

Congo. Republic of

Costa Rica

Côte d'Ivoire

Croatia

Cuba

Cyprus

Czech Republic

Denmark

Djibouti

Dominica

Dominican Republic

Ecuador
46.7

44.5

78.7

52.5

70.7

51.4

142

40.6

172

43.7

169

53

$57.7 \quad 107$

60.4

87

28.7

177

46

72.2

26

76.1

10

55.9

65.2

61.3

80

159

48.0

118

63

64.2

60.9

47.4

159

79.1

$50.5 \quad 142$

32

$50.1 \quad 144$

$39.5 \quad 172$

$42.3 \quad 169$

$67.1 \quad 54$

$56.9 \quad 109$

$61.3 \quad 80$

$28.3 \quad 177$

67.5

48

71.9

27

75.5

13

5.1

121

0

$\begin{array}{lll}43.4 & 168 & -1\end{array}$

2

$-2$

0

$-1$

$-2$

7

$-2$

$-1$

$-3$

$-3$ 
Egypt

El Salvador

Equatorial Guinea

Eritrea

Estonia

Ethiopia

Fiji

Finland

France

Gabon

Gambia

Georgia

Germany

Ghana

Greece

Guatemala

Guinea

Guinea-Bissau

Guyana
52.9

66.2

44.4

38.5

75.9

50.0

58.7

73.4

63.5

57.8

59.5

72.6

73.4

64.2

55.7

61.2

53.5

51.3

55.7

135

59

168

174

11

151

99

19

70

105

92

22

18

66

119

83

133

143

121

53.6

61.0

51.6

136

$-3$

49.8

147

$-4$ 


\begin{tabular}{|c|c|c|c|c|c|}
\hline Haiti & 48.9 & 156 & 46.8 & 160 & -4 \\
\hline Honduras & 57.1 & 112 & 58.6 & 96 & 16 \\
\hline Hong Kong SAR & 90.1 & 1 & 90.1 & 1 & 0 \\
\hline Hungary & 67.0 & 51 & 67.5 & 47 & 4 \\
\hline Iceland & 72.4 & 23 & 73.4 & 22 & 1 \\
\hline India & 55.7 & 120 & 54.0 & 126 & -6 \\
\hline Indonesia & 58.5 & 100 & 58.4 & 97 & 3 \\
\hline Iran & 40.3 & 173 & 39.5 & 173 & 0 \\
\hline Ireland & 76.2 & 9 & 76.3 & 10 & -1 \\
\hline Israel & 68.4 & 44 & 68.7 & 40 & 4 \\
\hline Italy & 60.9 & 86 & 61.3 & 81 & 5 \\
\hline Jamaica & 66.7 & 56 & 65.9 & 58 & -2 \\
\hline Japan & 72.4 & 25 & 71.5 & 29 & -4 \\
\hline Jordan & 69.2 & 39 & 69.0 & 37 & 2 \\
\hline Kazakhstan & 63.7 & 67 & 61.8 & 77 & -10 \\
\hline Kenya & 57.1 & 111 & 56.1 & 112 & -1 \\
\hline Kiribati & 46.3 & 164 & 43.7 & 165 & -1 \\
\hline Korea. North & 1.0 & 178 & 1.1 & 178 & 0 \\
\hline Korea. South & 71.2 & 31 & 72.7 & 23 & 8 \\
\hline
\end{tabular}


Kuwait

Kyrgyz Republic

Lao P.D.R.

Latvia

Lebanon

Lesotho

Liberia

Lithuania

Luxembourg

Macau

Macedonia

Madagascar

Malawi

Malaysia

Maldives

Mali

Malta

Mauritania

Mauritius
62.3

76

61.1

51.2

68.7

59.4

96

49.5

52.4

138

73.0

21

16

29

71.3

68.6

43

61.7

79

55.4

124

37

$51.0 \quad 145$

55.5

66.4

53.2

134

8

76.5

$69.6 \quad 37$

122

58

62.3

75

1

59.6

90

$-5$

$49.9 \quad 146 \quad-2$

68.5

41

1

59.1

93

3

$48.6 \quad 154$

0

$52.0 \quad 133$

5

74.3

20

1

76.2

11

5

71.7

28

1

68.8

39

$-2$

49.9

145

0

54.0

127

$-5$

66.9

56

2

132

2 
Mexico

Micronesia

Moldova

Mongolia

Montenegro

Morocco

Mozambique

Namibia

Nepal

Netherlands

New Zealand

Nicaragua

Niger

Nigeria

Norway

Oman

Pakistan

Panama

Papua New Guinea

Paraguay

Peru

Philippines

Poland

Portugal

Qatar

Romania

Russia

Rwanda

Saint. Lucia

Saint. Vincent and the Grenadines

Samoa

São Tomé and Príncipe

Saudi Arabia

Senegal
66.8

55

49.8

153

57.3

110

58.9

97

63.6

68

$58.3 \quad 103$

55.0

128

59.4

94

50.1

149

74.2

81.2

58.4

55.1

54.3

70.9

67.4

55.2

63.4

53.9

62.0

67.4

60.1

67.0

63.5

71.2

65.5

51.9

64.7

70.7

67.0

61.1

48.8

62.2

55.4

125

66.9

57

$-2$

48.1

157

58.2

99

11

$57.6 \quad 101$

$-4$

63.3

70

$-2$

59.8

88

15

$55.4 \quad 116$

12

$\begin{array}{ll}57.1 & 107\end{array}$

$-13$

$49.4 \quad 148$

$75.3 \quad 15$

80.95

$57.5 \quad 102$

$54.5 \quad 125$

$53.0 \quad 131$

$72.1 \quad 25$

$67.1 \quad 51$

$55.0 \quad 122$

$64.7 \quad 64$

$51.3 \quad 138$

$63.6 \quad 69$

67.1

59.9

67.4

65.1

71.0

65.3

51.0

62.8

69.4

65.6

59.7

48.9

61.4

55.2
55

87

49

62

31

61

139

73

35

60

89

150

79

119
1

0

0

2

2

$-2$

7

$-3$

4

7




\begin{tabular}{|c|c|c|c|c|c|}
\hline Serbia & 59.4 & 95 & 59.0 & 94 & 1 \\
\hline Seychelles & 56.2 & 117 & 55.2 & 118 & -1 \\
\hline Sierra Leone & 50.5 & 148 & 50.9 & 140 & 8 \\
\hline Singapore & 89.4 & 2 & 89.0 & 2 & 0 \\
\hline Slovak Republic & 66.4 & 57 & 67.2 & 50 & 7 \\
\hline Slovenia & 62.7 & 74 & 63.1 & 72 & 2 \\
\hline Solomon Islands & 46.2 & 165 & 44.2 & 163 & 2 \\
\hline South Africa & 62.5 & 75 & 62.5 & 74 & 1 \\
\hline Spain & 67.2 & 49 & 67.9 & 43 & 6 \\
\hline Sri Lanka & 60.0 & 90 & 59.5 & 91 & -1 \\
\hline Suriname & 54.2 & 130 & 51.4 & 137 & -7 \\
\hline Swaziland & 61.2 & 82 & 59.9 & 85 & -3 \\
\hline Sweden & 73.1 & 20 & 74.3 & 19 & 1 \\
\hline Switzerland & 81.6 & 4 & 81.0 & 4 & 0 \\
\hline Taiwan & 73.9 & 17 & 74.8 & 18 & -1 \\
\hline Tajikistan & 52.0 & 139 & 51.8 & 134 & 5 \\
\hline Tanzania & 57.8 & 106 & 57.1 & 108 & -2 \\
\hline Thailand & 63.3 & 72 & 63.2 & 71 & 1 \\
\hline Timor-Leste & 43.2 & 170 & 40.7 & 171 & -1 \\
\hline Togo & 49.9 & 152 & 49.1 & 149 & 3 \\
\hline Tonga & 58.2 & 104 & 55.2 & 117 & -13 \\
\hline Trinidad and Tobago & 62.7 & 73 & 61.7 & 78 & -5 \\
\hline Tunisia & 57.3 & 109 & 55.7 & 113 & -4 \\
\hline Turkey & 64.9 & 64 & 65.0 & 63 & 1 \\
\hline Turkmenistan & 42.2 & 171 & 41.5 & 170 & 1 \\
\hline Uganda & 59.9 & 91 & 57.5 & 103 & -12 \\
\hline Ukraine & 49.3 & 155 & 48.4 & 155 & 0 \\
\hline United Arab Emirates & 71.4 & 28 & 70.0 & 33 & -5 \\
\hline United Kingdom & 74.9 & 14 & 75.4 & 14 & 0 \\
\hline United States & 75.5 & 12 & 74.1 & 21 & -9 \\
\hline Uruguay & 69.3 & 38 & 69.0 & 38 & 0 \\
\hline Uzbekistan & 46.5 & 163 & 44.8 & 162 & 1 \\
\hline Vanuatu & 59.5 & 93 & 59.4 & 92 & 1 \\
\hline Venezuela & 36.3 & 175 & 35.9 & 174 & 1 \\
\hline Vietnam & 50.8 & 147 & 48.7 & 153 & -6 \\
\hline Yemen & 55.5 & 123 & 55.1 & 120 & 3 \\
\hline Zambia & 60.4 & 88 & 60.3 & 84 & 4 \\
\hline Zimbabwe & 35.5 & 176 & 34.8 & 176 & 0 \\
\hline Brunei Darussalam & 69.0 & 40 & 67.1 & 52 & -12 \\
\hline
\end{tabular}

Table 10: Country specific Weights generated by BOD

\begin{tabular}{|c|c|c|c|c|c|c|c|c|c|c|}
\hline $\begin{array}{c}\text { Country } \\
\text { Name }\end{array}$ & $\begin{array}{l}\text { Property } \\
\text { Rights }\end{array}$ & $\begin{array}{c}\text { Freedom } \\
\text { from } \\
\text { Corruption }\end{array}$ & $\begin{array}{l}\text { Fiscal } \\
\text { Freedom }\end{array}$ & $\begin{array}{c}\text { Gov't } \\
\text { Spending }\end{array}$ & $\begin{array}{l}\text { Business } \\
\text { Freedom }\end{array}$ & $\begin{array}{l}\text { Labor } \\
\text { Freedom }\end{array}$ & $\begin{array}{l}\text { Monetary } \\
\text { Freedom }\end{array}$ & $\begin{array}{l}\text { Trade } \\
\text { Freedom }\end{array}$ & $\begin{array}{l}\text { Investment } \\
\text { Freedom }\end{array}$ & $\begin{array}{l}\text { Financial } \\
\text { Freedom }\end{array}$ \\
\hline
\end{tabular}

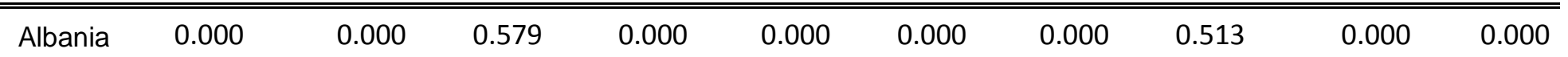




\begin{tabular}{|c|c|c|c|c|c|c|c|c|c|c|}
\hline Algeria & 0.000 & 0.000 & 0.758 & 0.000 & 0.215 & 0.000 & 0.101 & 0.000 & 0.000 & 0.000 \\
\hline Angola & 0.000 & 0.000 & 0.908 & 0.000 & 0.000 & 0.000 & 0.000 & 0.113 & 0.005 & 0.000 \\
\hline Argentina & 0.000 & 0.000 & 0.000 & 0.000 & 0.000 & 0.000 & 0.000 & 1.111 & 0.000 & 0.000 \\
\hline Armenia & 0.000 & 0.000 & 0.000 & 0.000 & 0.000 & 0.000 & 0.000 & 1.111 & 0.000 & 0.000 \\
\hline Australia & 0.533 & 0.275 & 0.000 & 0.055 & 0.000 & 0.000 & 0.000 & 0.000 & 0.000 & 0.272 \\
\hline Austria & 0.729 & 0.000 & 0.000 & 0.000 & 0.000 & 0.033 & 0.000 & 0.000 & 0.347 & 0.000 \\
\hline Azerbaijan & 0.000 & 0.000 & 0.208 & 0.000 & 0.000 & 0.000 & 0.910 & 0.000 & 0.067 & 0.000 \\
\hline Bahamas & 0.098 & 0.000 & 0.817 & 0.107 & 0.000 & 0.041 & 0.000 & 0.000 & 0.000 & 0.019 \\
\hline Bahrain & 0.000 & 0.000 & 0.684 & 0.000 & 0.000 & 0.000 & 0.000 & 0.372 & 0.032 & 0.000 \\
\hline Bangladesh & 0.000 & 0.000 & 0.000 & 1.029 & 0.064 & 0.000 & 0.000 & 0.000 & 0.000 & 0.000 \\
\hline Barbados & 0.061 & 0.089 & 0.221 & 0.000 & 0.000 & 0.000 & 0.812 & 0.000 & 0.000 & 0.000 \\
\hline Belarus & 0.000 & 0.000 & 0.579 & 0.000 & 0.000 & 0.000 & 0.000 & 0.513 & 0.000 & 0.000 \\
\hline Belgium & 0.000 & 0.000 & 0.000 & 0.000 & 0.000 & 0.000 & 0.000 & 1.111 & 0.000 & 0.000 \\
\hline Belize & 0.000 & 0.000 & 0.025 & 0.074 & 0.091 & 0.000 & 1.001 & 0.000 & 0.000 & 0.000 \\
\hline Benin & 0.000 & 0.000 & 0.000 & 0.774 & 0.000 & 0.000 & 0.351 & 0.000 & 0.010 & 0.000 \\
\hline Bhutan & 0.000 & 0.000 & 0.698 & 0.000 & 0.000 & 0.368 & 0.000 & 0.000 & 0.000 & 0.000 \\
\hline $\begin{array}{r}\text { Bolivia } \\
\text { Bosnia and }\end{array}$ & 0.000 & 0.000 & 0.579 & 0.000 & 0.000 & 0.000 & 0.000 & 0.513 & 0.000 & 0.000 \\
\hline Herzegovina & 0.000 & 0.000 & 0.000 & 0.000 & 0.000 & 0.000 & 0.000 & 1.111 & 0.000 & 0.000 \\
\hline Botswana & 0.000 & 0.000 & 0.000 & 0.000 & 0.000 & 0.000 & 0.000 & 1.111 & 0.000 & 0.000 \\
\hline Brazil & 0.000 & 0.000 & 0.126 & 0.010 & 0.000 & 0.000 & 0.975 & 0.000 & 0.000 & 0.082 \\
\hline Bulgaria & 0.000 & 0.000 & 0.579 & 0.000 & 0.000 & 0.000 & 0.000 & 0.513 & 0.000 & 0.000 \\
\hline Burkina Faso & 0.000 & 0.000 & 0.187 & 0.406 & 0.000 & 0.000 & 0.564 & 0.000 & 0.000 & 0.000 \\
\hline Burma & 0.000 & 0.000 & 0.073 & 0.989 & 0.000 & 0.032 & 0.000 & 0.000 & 0.000 & 0.000 \\
\hline Burundi & 0.000 & 0.000 & 0.098 & 0.000 & 0.000 & 0.000 & 0.752 & 0.322 & 0.003 & 0.000 \\
\hline Cambodia & 0.000 & 0.000 & 0.300 & 0.658 & 0.000 & 0.000 & 0.155 & 0.000 & 0.000 & 0.000 \\
\hline Cameroon & 0.000 & 0.000 & 0.000 & 1.041 & 0.000 & 0.052 & 0.000 & 0.000 & 0.000 & 0.000 \\
\hline Canada & 0.437 & 0.000 & 0.000 & 0.000 & 0.000 & 0.000 & 0.000 & 0.674 & 0.000 & 0.000 \\
\hline $\begin{array}{r}\text { Cape Verde } \\
\text { Central } \\
\text { African }\end{array}$ & 0.033 & 0.000 & 0.157 & 0.007 & 0.000 & 0.000 & 0.952 & 0.000 & 0.041 & 0.000 \\
\hline Republic & 0.000 & 0.000 & 0.000 & 1.069 & 0.000 & 0.000 & 0.000 & 0.000 & 0.000 & 0.000 \\
\hline Chad & 0.000 & 0.000 & 0.000 & 0.781 & 0.000 & 0.005 & 0.348 & 0.000 & 0.000 & 0.000 \\
\hline Chile & 0.800 & 0.000 & 0.000 & 0.088 & 0.000 & 0.000 & 0.245 & 0.000 & 0.000 & 0.000 \\
\hline China & 0.000 & 0.000 & 0.000 & 0.781 & 0.000 & 0.005 & 0.348 & 0.000 & 0.000 & 0.000 \\
\hline Colombia & 0.000 & 0.000 & 0.000 & 0.085 & 0.098 & 0.000 & 1.008 & 0.000 & 0.000 & 0.000 \\
\hline $\begin{array}{r}\text { Comoros } \\
\text { Congo. } \\
\text { Democratic }\end{array}$ & 0.000 & 0.000 & 0.000 & 0.781 & 0.000 & 0.005 & 0.348 & 0.000 & 0.000 & 0.000 \\
\hline $\begin{array}{r}\text { Republic of } \\
\text { the Congo } \\
\text { Congo. }\end{array}$ & 0.000 & 0.000 & 0.076 & 0.818 & 0.000 & 0.000 & 0.227 & 0.000 & 0.000 & 0.000 \\
\hline Republic of & 0.000 & 0.000 & 0.000 & 0.781 & 0.000 & 0.005 & 0.348 & 0.000 & 0.000 & 0.000 \\
\hline Costa Rica & 0.039 & 0.000 & 0.000 & 1.058 & 0.000 & 0.000 & 0.000 & 0.000 & 0.000 & 0.000 \\
\hline Côte d'Ivoire & 0.000 & 0.000 & 0.009 & 0.093 & 0.017 & 0.000 & 0.894 & 0.177 & 0.000 & 0.000 \\
\hline Croatia & 0.000 & 0.000 & 0.000 & 0.000 & 0.000 & 0.000 & 0.000 & 1.111 & 0.000 & 0.000 \\
\hline Cuba & 0.000 & 0.000 & 0.093 & 0.000 & 0.000 & 0.000 & 0.983 & 0.092 & 0.000 & 0.000 \\
\hline Cyprus & 0.000 & 0.000 & 0.096 & 0.000 & 0.002 & 0.000 & 0.743 & 0.334 & 0.000 & 0.000 \\
\hline
\end{tabular}




\begin{tabular}{|c|c|c|c|c|c|c|c|c|c|c|}
\hline $\begin{array}{r}\text { Czech } \\
\text { Republic }\end{array}$ & 0.000 & 0.000 & 0.000 & 0.000 & 0.000 & 0.000 & 0.000 & 1.111 & 0.000 & 0.000 \\
\hline Denmark & 0.000 & 0.000 & 0.000 & 0.000 & 0.000 & 0.000 & 0.000 & 0.000 & 0.000 & 1.111 \\
\hline Djibouti & 0.000 & 0.000 & 0.208 & 0.000 & 0.000 & 0.000 & 0.910 & 0.000 & 0.067 & 0.000 \\
\hline $\begin{array}{l}\text { Dominica } \\
\text { Dominican }\end{array}$ & 0.000 & 0.000 & 0.000 & 0.085 & 0.098 & 0.000 & 1.008 & 0.000 & 0.000 & 0.000 \\
\hline Republic & 0.000 & 0.000 & 0.027 & 0.976 & 0.000 & 0.000 & 0.000 & 0.000 & 0.101 & 0.000 \\
\hline Ecuador & 0.000 & 0.000 & 0.579 & 0.000 & 0.000 & 0.000 & 0.000 & 0.513 & 0.000 & 0.000 \\
\hline Egypt & 0.000 & 0.000 & 0.684 & 0.000 & 0.000 & 0.000 & 0.000 & 0.372 & 0.032 & 0.000 \\
\hline $\begin{array}{l}\text { El Salvador } \\
\text { Equatorial }\end{array}$ & 0.000 & 0.000 & 0.000 & 0.570 & 0.000 & 0.000 & 0.538 & 0.000 & 0.000 & 0.053 \\
\hline Guinea & 0.000 & 0.000 & 0.162 & 0.000 & 0.000 & 0.000 & 0.991 & 0.000 & 0.000 & 0.000 \\
\hline Eritrea & 0.000 & 0.000 & 0.000 & 0.000 & 0.000 & 0.000 & 0.000 & 1.111 & 0.000 & 0.000 \\
\hline Estonia & 0.777 & 0.000 & 0.047 & 0.000 & 0.000 & 0.000 & 0.000 & 0.000 & 0.285 & 0.000 \\
\hline Ethiopia & 0.000 & 0.000 & 0.000 & 1.041 & 0.000 & 0.052 & 0.000 & 0.000 & 0.000 & 0.000 \\
\hline Fiji & 0.000 & 0.000 & 0.000 & 0.089 & 0.000 & 0.115 & 0.979 & 0.000 & 0.009 & 0.000 \\
\hline Finland & 0.642 & 0.054 & 0.011 & 0.000 & 0.057 & 0.000 & 0.000 & 0.000 & 0.346 & 0.000 \\
\hline France & 0.000 & 0.000 & 0.000 & 0.000 & 0.000 & 0.000 & 0.000 & 1.111 & 0.000 & 0.000 \\
\hline Gabon & 0.000 & 0.000 & 0.000 & 0.781 & 0.000 & 0.005 & 0.348 & 0.000 & 0.000 & 0.000 \\
\hline Gambia & 0.000 & 0.000 & 0.018 & 0.770 & 0.000 & 0.000 & 0.346 & 0.000 & 0.000 & 0.000 \\
\hline Georgia & 0.000 & 0.000 & 0.000 & 0.000 & 0.000 & 0.000 & 0.000 & 1.111 & 0.000 & 0.000 \\
\hline Germany & 0.706 & 0.000 & 0.000 & 0.000 & 0.064 & 0.000 & 0.000 & 0.000 & 0.335 & 0.000 \\
\hline Ghana & 0.000 & 0.000 & 0.366 & 0.701 & 0.000 & 0.000 & 0.000 & 0.000 & 0.032 & 0.000 \\
\hline Greece & 0.000 & 0.000 & 0.000 & 0.000 & 0.000 & 0.000 & 0.000 & 1.111 & 0.000 & 0.000 \\
\hline Guatemala & 0.000 & 0.000 & 0.000 & 1.069 & 0.000 & 0.000 & 0.000 & 0.000 & 0.000 & 0.000 \\
\hline $\begin{array}{l}\text { Guinea } \\
\text { Guinea- }\end{array}$ & 0.000 & 0.000 & 0.000 & 1.041 & 0.000 & 0.052 & 0.000 & 0.000 & 0.000 & 0.000 \\
\hline Bissau & 0.000 & 0.000 & 0.420 & 0.556 & 0.000 & 0.012 & 0.121 & 0.000 & 0.000 & 0.000 \\
\hline Guyana & 0.000 & 0.000 & 0.000 & 0.074 & 0.000 & 0.112 & 0.999 & 0.000 & 0.004 & 0.000 \\
\hline Haiti & 0.000 & 0.000 & 0.147 & 0.000 & 0.000 & 0.000 & 0.923 & 0.066 & 0.052 & 0.000 \\
\hline $\begin{array}{l}\text { Honduras } \\
\text { Hong Kong }\end{array}$ & 0.000 & 0.000 & 0.187 & 0.406 & 0.000 & 0.000 & 0.564 & 0.000 & 0.000 & 0.000 \\
\hline SAR & 1.013 & 0.000 & 0.000 & 0.086 & 0.000 & 0.000 & 0.000 & 0.000 & 0.000 & 0.013 \\
\hline Hungary & 0.000 & 0.000 & 0.000 & 0.000 & 0.000 & 0.000 & 0.000 & 1.111 & 0.000 & 0.000 \\
\hline Iceland & 0.437 & 0.000 & 0.000 & 0.000 & 0.000 & 0.000 & 0.000 & 0.674 & 0.000 & 0.000 \\
\hline India & 0.000 & 0.000 & 0.484 & 0.566 & 0.000 & 0.045 & 0.000 & 0.000 & 0.000 & 0.000 \\
\hline Indonesia & 0.000 & 0.000 & 0.109 & 0.958 & 0.000 & 0.000 & 0.000 & 0.000 & 0.000 & 0.034 \\
\hline Iran & 0.000 & 0.000 & 0.092 & 0.970 & 0.032 & 0.000 & 0.000 & 0.000 & 0.000 & 0.000 \\
\hline Ireland & 0.328 & 0.000 & 0.000 & 0.000 & 0.000 & 0.000 & 0.408 & 0.108 & 0.303 & 0.000 \\
\hline Israel & 0.000 & 0.000 & 0.000 & 0.000 & 0.000 & 0.000 & 0.961 & 0.005 & 0.208 & 0.000 \\
\hline Italy & 0.000 & 0.000 & 0.000 & 0.000 & 0.000 & 0.000 & 0.000 & 1.111 & 0.000 & 0.000 \\
\hline Jamaica & 0.000 & 0.000 & 0.000 & 0.000 & 0.040 & 0.000 & 0.557 & 0.000 & 0.560 & 0.000 \\
\hline Japan & 0.032 & 0.044 & 0.039 & 0.084 & 0.017 & 0.000 & 0.983 & 0.000 & 0.000 & 0.000 \\
\hline Jordan & 0.000 & 0.000 & 0.485 & 0.000 & 0.000 & 0.000 & 0.576 & 0.000 & 0.085 & 0.000 \\
\hline Kazakhstan & 0.000 & 0.000 & 0.564 & 0.483 & 0.000 & 0.043 & 0.000 & 0.000 & 0.000 & 0.000 \\
\hline Kenya & 0.000 & 0.000 & 0.027 & 0.087 & 0.000 & 0.000 & 0.874 & 0.193 & 0.007 & 0.000 \\
\hline Kiribati & 0.000 & 0.000 & 0.084 & 0.000 & 0.000 & 0.096 & 0.989 & 0.000 & 0.000 & 0.000 \\
\hline Korea. North & 0.000 & 1.063 & 0.000 & 0.000 & 0.000 & 0.000 & 0.000 & 0.000 & 0.000 & 0.000 \\
\hline Korea. South & 0.000 & 0.000 & 0.000 & 0.067 & 0.134 & 0.000 & 0.985 & 0.000 & 0.000 & 0.000 \\
\hline
\end{tabular}




\begin{tabular}{|c|c|c|c|c|c|c|c|c|c|c|}
\hline $\begin{array}{l}\text { Kuwait } \\
\text { Kyrgyz }\end{array}$ & 0.000 & 0.000 & 1.001 & 0.000 & 0.000 & 0.000 & 0.000 & 0.000 & 0.000 & 0.000 \\
\hline Republic & 0.000 & 0.000 & 0.705 & 0.000 & 0.000 & 0.357 & 0.000 & 0.000 & 0.003 & 0.000 \\
\hline Lao P.D.R. & 0.000 & 0.000 & 0.300 & 0.658 & 0.000 & 0.000 & 0.155 & 0.000 & 0.000 & 0.000 \\
\hline Latvia & 0.000 & 0.000 & 0.000 & 0.000 & 0.000 & 0.000 & 0.000 & 1.111 & 0.000 & 0.000 \\
\hline Lebanon & 0.000 & 0.000 & 0.737 & 0.131 & 0.000 & 0.000 & 0.000 & 0.169 & 0.050 & 0.000 \\
\hline Lesotho & 0.000 & 0.000 & 0.093 & 0.000 & 0.000 & 0.000 & 0.983 & 0.092 & 0.000 & 0.000 \\
\hline Liberia & 0.000 & 0.000 & 0.208 & 0.000 & 0.000 & 0.000 & 0.910 & 0.000 & 0.067 & 0.000 \\
\hline Lithuania & 0.000 & 0.000 & 0.579 & 0.000 & 0.000 & 0.000 & 0.000 & 0.513 & 0.000 & 0.000 \\
\hline Luxembourg & 0.834 & 0.000 & 0.000 & 0.029 & 0.000 & 0.000 & 0.000 & 0.000 & 0.248 & 0.000 \\
\hline Macau & 0.000 & 0.000 & 0.020 & 0.744 & 0.000 & 0.000 & 0.000 & 0.337 & 0.000 & 0.000 \\
\hline Macedonia & 0.000 & 0.000 & 0.097 & 0.000 & 0.000 & 0.000 & 0.738 & 0.339 & 0.000 & 0.000 \\
\hline Madagascar & 0.000 & 0.000 & 0.076 & 0.818 & 0.000 & 0.000 & 0.227 & 0.000 & 0.000 & 0.000 \\
\hline Malawi & 0.000 & 0.000 & 0.579 & 0.000 & 0.000 & 0.000 & 0.000 & 0.513 & 0.000 & 0.000 \\
\hline Malaysia & 0.000 & 0.000 & 0.025 & 0.074 & 0.091 & 0.000 & 1.001 & 0.000 & 0.000 & 0.000 \\
\hline Maldives & 0.000 & 0.000 & 0.800 & 0.000 & 0.220 & 0.040 & 0.000 & 0.000 & 0.000 & 0.000 \\
\hline Mali & 0.000 & 0.000 & 0.000 & 0.381 & 0.000 & 0.000 & 0.647 & 0.140 & 0.000 & 0.000 \\
\hline Malta & 0.000 & 0.000 & 0.000 & 0.000 & 0.000 & 0.000 & 0.000 & 1.111 & 0.000 & 0.000 \\
\hline Mauritania & 0.000 & 0.000 & 0.208 & 0.000 & 0.000 & 0.000 & 0.910 & 0.000 & 0.067 & 0.000 \\
\hline Mauritius & 0.000 & 0.000 & 0.579 & 0.000 & 0.000 & 0.000 & 0.000 & 0.513 & 0.000 & 0.000 \\
\hline Mexico & 0.000 & 0.000 & 0.000 & 0.000 & 0.000 & 0.000 & 0.000 & 1.111 & 0.000 & 0.000 \\
\hline Micronesia & 0.000 & 0.000 & 0.579 & 0.000 & 0.000 & 0.000 & 0.000 & 0.513 & 0.000 & 0.000 \\
\hline Moldova & 0.000 & 0.000 & 0.579 & 0.000 & 0.000 & 0.000 & 0.000 & 0.513 & 0.000 & 0.000 \\
\hline Mongolia & 0.000 & 0.000 & 0.108 & 0.000 & 0.000 & 0.227 & 0.833 & 0.000 & 0.000 & 0.000 \\
\hline Montenegro & 0.000 & 0.000 & 0.684 & 0.000 & 0.000 & 0.000 & 0.000 & 0.372 & 0.032 & 0.000 \\
\hline Morocco & 0.000 & 0.000 & 0.000 & 0.085 & 0.098 & 0.000 & 1.008 & 0.000 & 0.000 & 0.000 \\
\hline Mozambique & 0.000 & 0.000 & 0.061 & 0.024 & 0.000 & 0.000 & 0.953 & 0.119 & 0.000 & 0.028 \\
\hline Namibia & 0.000 & 0.000 & 0.000 & 0.000 & 0.000 & 0.000 & 0.000 & 1.111 & 0.000 & 0.000 \\
\hline Nepal & 0.000 & 0.000 & 0.076 & 0.818 & 0.000 & 0.000 & 0.227 & 0.000 & 0.000 & 0.000 \\
\hline Netherlands & 0.419 & 0.086 & 0.000 & 0.000 & 0.000 & 0.000 & 0.000 & 0.450 & 0.164 & 0.000 \\
\hline New Zealand & 0.741 & 0.000 & 0.000 & 0.000 & 0.000 & 0.000 & 0.000 & 0.000 & 0.247 & 0.123 \\
\hline Nicaragua & 0.000 & 0.000 & 0.000 & 0.000 & 0.000 & 0.000 & 0.000 & 1.111 & 0.000 & 0.000 \\
\hline Niger & 0.000 & 0.000 & 0.000 & 0.784 & 0.000 & 0.000 & 0.347 & 0.000 & 0.000 & 0.000 \\
\hline Nigeria & 0.000 & 0.000 & 0.253 & 0.432 & 0.000 & 0.000 & 0.460 & 0.000 & 0.000 & 0.000 \\
\hline Norway & 0.437 & 0.000 & 0.000 & 0.000 & 0.000 & 0.000 & 0.000 & 0.674 & 0.000 & 0.000 \\
\hline Oman & 0.000 & 0.000 & 0.684 & 0.000 & 0.000 & 0.000 & 0.000 & 0.372 & 0.032 & 0.000 \\
\hline Pakistan & 0.000 & 0.000 & 0.092 & 0.970 & 0.032 & 0.000 & 0.000 & 0.000 & 0.000 & 0.000 \\
\hline $\begin{array}{r}\text { Panama } \\
\text { Papua New }\end{array}$ & 0.000 & 0.000 & 0.208 & 0.000 & 0.000 & 0.000 & 0.910 & 0.000 & 0.067 & 0.000 \\
\hline Guinea & 0.000 & 0.000 & 0.000 & 0.000 & 0.000 & 0.000 & 0.000 & 1.111 & 0.000 & 0.000 \\
\hline Paraguay & 0.000 & 0.000 & 0.418 & 0.579 & 0.021 & 0.000 & 0.088 & 0.000 & 0.000 & 0.000 \\
\hline Peru & 0.000 & 0.000 & 0.000 & 0.381 & 0.000 & 0.000 & 0.647 & 0.140 & 0.000 & 0.000 \\
\hline Philippines & 0.000 & 0.000 & 0.000 & 0.776 & 0.005 & 0.000 & 0.354 & 0.000 & 0.000 & 0.000 \\
\hline Poland & 0.000 & 0.000 & 0.000 & 0.000 & 0.000 & 0.000 & 0.000 & 1.111 & 0.000 & 0.000 \\
\hline Portugal & 0.000 & 0.000 & 0.000 & 0.000 & 0.000 & 0.000 & 0.000 & 1.111 & 0.000 & 0.000 \\
\hline Qatar & 0.030 & 0.000 & 0.712 & 0.000 & 0.000 & 0.000 & 0.000 & 0.322 & 0.023 & 0.000 \\
\hline Romania & 0.000 & 0.000 & 0.000 & 0.000 & 0.000 & 0.000 & 0.000 & 1.111 & 0.000 & 0.000 \\
\hline
\end{tabular}




\begin{tabular}{|c|c|c|c|c|c|c|c|c|c|c|}
\hline Russia & 0.000 & 0.000 & 0.579 & 0.000 & 0.000 & 0.000 & 0.000 & 0.513 & 0.000 & 0.000 \\
\hline Rwanda & 0.000 & 0.000 & 0.000 & 0.073 & 0.000 & 0.157 & 0.957 & 0.000 & 0.000 & 0.000 \\
\hline $\begin{array}{r}\text { Saint. Lucia } \\
\text { Saint. } \\
\text { Vincent and } \\
\text { the }\end{array}$ & 0.000 & 0.000 & 0.015 & 0.049 & 0.004 & 0.167 & 0.948 & 0.000 & 0.000 & 0.000 \\
\hline Grenadines & 0.014 & 0.000 & 0.000 & 0.085 & 0.019 & 0.082 & 0.993 & 0.000 & 0.000 & 0.000 \\
\hline $\begin{array}{r}\text { Samoa } \\
\text { São Tomé }\end{array}$ & 0.000 & 0.000 & 0.108 & 0.000 & 0.000 & 0.227 & 0.833 & 0.000 & 0.000 & 0.000 \\
\hline and Príncipe & 0.000 & 0.000 & 0.684 & 0.000 & 0.000 & 0.000 & 0.000 & 0.372 & 0.032 & 0.000 \\
\hline Saudi Arabia & 0.000 & 0.000 & 1.000 & 0.000 & 0.000 & 0.001 & 0.000 & 0.000 & 0.000 & 0.000 \\
\hline Senegal & 0.000 & 0.000 & 0.000 & 0.096 & 0.000 & 0.000 & 0.885 & 0.204 & 0.000 & 0.000 \\
\hline Serbia & 0.000 & 0.000 & 0.684 & 0.000 & 0.000 & 0.000 & 0.000 & 0.372 & 0.032 & 0.000 \\
\hline Seychelles & 0.000 & 0.000 & 0.159 & 0.000 & 0.025 & 0.000 & 0.951 & 0.000 & 0.052 & 0.000 \\
\hline Sierra Leone & 0.000 & 0.000 & 0.135 & 0.931 & 0.000 & 0.000 & 0.000 & 0.000 & 0.033 & 0.000 \\
\hline $\begin{array}{r}\text { Singapore } \\
\text { Slovak }\end{array}$ & 1.023 & 0.000 & 0.000 & 0.087 & 0.000 & 0.000 & 0.000 & 0.000 & 0.000 & 0.000 \\
\hline Republic & 0.000 & 0.000 & 0.000 & 0.000 & 0.000 & 0.000 & 0.000 & 1.111 & 0.000 & 0.000 \\
\hline $\begin{array}{l}\text { Slovenia } \\
\text { Solomon }\end{array}$ & 0.000 & 0.000 & 0.000 & 0.000 & 0.000 & 0.000 & 0.000 & 1.111 & 0.000 & 0.000 \\
\hline Islands & 0.000 & 0.000 & 0.083 & 0.000 & 0.000 & 0.000 & 0.886 & 0.203 & 0.000 & 0.000 \\
\hline South Africa & 0.000 & 0.000 & 0.000 & 0.079 & 0.047 & 0.000 & 0.946 & 0.119 & 0.000 & 0.000 \\
\hline Spain & 0.000 & 0.000 & 0.000 & 0.000 & 0.000 & 0.000 & 0.000 & 1.111 & 0.000 & 0.000 \\
\hline Sri Lanka & 0.000 & 0.000 & 0.092 & 0.970 & 0.032 & 0.000 & 0.000 & 0.000 & 0.000 & 0.000 \\
\hline Suriname & 0.000 & 0.000 & 0.000 & 0.145 & 0.000 & 0.113 & 0.929 & 0.000 & 0.000 & 0.000 \\
\hline Swaziland & 0.000 & 0.000 & 0.000 & 0.000 & 0.000 & 0.000 & 0.000 & 1.111 & 0.000 & 0.000 \\
\hline Sweden & 0.405 & 0.003 & 0.000 & 0.000 & 0.025 & 0.000 & 0.356 & 0.000 & 0.351 & 0.000 \\
\hline Switzerland & 0.428 & 0.021 & 0.000 & 0.080 & 0.000 & 0.000 & 0.569 & 0.065 & 0.000 & 0.000 \\
\hline Taiwan & 0.000 & 0.000 & 0.000 & 0.085 & 0.098 & 0.000 & 1.008 & 0.000 & 0.000 & 0.000 \\
\hline Tajikistan & 0.000 & 0.000 & 0.731 & 0.327 & 0.000 & 0.000 & 0.000 & 0.000 & 0.000 & 0.000 \\
\hline Tanzania & 0.000 & 0.000 & 0.391 & 0.482 & 0.000 & 0.000 & 0.000 & 0.227 & 0.000 & 0.000 \\
\hline Thailand & 0.000 & 0.000 & 0.000 & 1.025 & 0.000 & 0.000 & 0.000 & 0.000 & 0.000 & 0.081 \\
\hline Timor-Leste & 0.000 & 0.000 & 0.000 & 0.000 & 0.000 & 0.491 & 0.646 & 0.000 & 0.000 & 0.000 \\
\hline Togo & 0.000 & 0.000 & 0.000 & 0.776 & 0.005 & 0.000 & 0.354 & 0.000 & 0.000 & 0.000 \\
\hline $\begin{array}{r}\text { Tonga } \\
\text { Trinidad and }\end{array}$ & 0.000 & 0.000 & 0.386 & 0.000 & 0.000 & 0.672 & 0.000 & 0.000 & 0.000 & 0.000 \\
\hline Tobago & 0.000 & 0.000 & 0.579 & 0.000 & 0.000 & 0.000 & 0.000 & 0.513 & 0.000 & 0.000 \\
\hline Tunisia & 0.000 & 0.000 & 0.025 & 0.074 & 0.091 & 0.000 & 1.001 & 0.000 & 0.000 & 0.000 \\
\hline Turkey & 0.000 & 0.000 & 0.000 & 0.000 & 0.000 & 0.000 & 0.000 & 1.111 & 0.000 & 0.000 \\
\hline Turkmenistan & 0.000 & 0.000 & 0.442 & 0.608 & 0.043 & 0.000 & 0.000 & 0.000 & 0.000 & 0.000 \\
\hline Uganda & 0.000 & 0.000 & 0.000 & 1.041 & 0.000 & 0.052 & 0.000 & 0.000 & 0.000 & 0.000 \\
\hline $\begin{array}{r}\text { Ukraine } \\
\text { United Arab }\end{array}$ & 0.000 & 0.000 & 0.000 & 0.000 & 0.000 & 0.000 & 0.000 & 1.111 & 0.000 & 0.000 \\
\hline $\begin{array}{r}\text { Emirates } \\
\text { United }\end{array}$ & 0.000 & 0.000 & 0.035 & 0.044 & 0.000 & 0.000 & 0.929 & 0.172 & 0.000 & 0.000 \\
\hline Kingdom & 0.706 & 0.000 & 0.000 & 0.000 & 0.064 & 0.000 & 0.000 & 0.000 & 0.335 & 0.000 \\
\hline United States & 0.062 & 0.000 & 0.000 & 0.000 & 0.000 & 0.979 & 0.000 & 0.000 & 0.000 & 0.000 \\
\hline Uruguay & 0.000 & 0.000 & 0.000 & 0.000 & 0.000 & 0.000 & 0.000 & 1.111 & 0.000 & 0.000 \\
\hline Uzbekistan & 0.000 & 0.000 & 0.808 & 0.052 & 0.204 & 0.000 & 0.000 & 0.000 & 0.000 & 0.000 \\
\hline Vanuatu & 0.000 & 0.000 & 0.485 & 0.000 & 0.000 & 0.000 & 0.576 & 0.000 & 0.085 & 0.000 \\
\hline
\end{tabular}




$\begin{array}{rrrrrrrrrrr}\text { Venezuela } & 0.000 & 0.000 & 0.579 & 0.000 & 0.000 & 0.000 & 0.000 & 0.513 & 0.000 & 0.000 \\ \text { Vietnam } & 0.000 & 0.000 & 0.000 & 0.000 & 0.000 & 0.000 & 0.000 & 1.111 & 0.000 & 0.000 \\ \text { Yemen } & 0.000 & 0.000 & 0.579 & 0.000 & 0.000 & 0.000 & 0.000 & 0.513 & 0.000 & 0.000 \\ \text { Zambia } & 0.000 & 0.000 & 0.000 & 0.000 & 0.000 & 0.000 & 0.000 & 1.111 & 0.000 & 0.000 \\ \text { Zimbabwe } & 0.000 & 0.000 & 0.104 & 0.000 & 0.037 & 0.000 & 1.027 & 0.000 & 0.000 & 0.000 \\ \text { Brunei } & & & & & & & & & 0.000 & 0.000 \\ \text { Darussalam } & 0.000 & 0.000 & 0.025 & 0.000 & 0.000 & 1.012 & 0.000 & 0.000 & 0.000 & 0.000\end{array}$

Table 11: Country specific scores generated by BOD

\begin{tabular}{|c|c|c|c|}
\hline Country Name & $\begin{array}{c}\text { score } \\
\text { with BOD } \\
\text { weighting }\end{array}$ & $\begin{array}{l}\text { Ranking } \\
\text { with } \\
\text { BOD }\end{array}$ & $\begin{array}{l}\text { Ranking } \\
\text { Variation }\end{array}$ \\
\hline Albania & 99 & 34 & 20 \\
\hline Algeria & 82 & 169 & -23 \\
\hline Angola & 88 & 146 & 14 \\
\hline Argentina & 77 & 174 & -8 \\
\hline Armenia & 95 & 81 & -40 \\
\hline Australia & 100 & 1 & 2 \\
\hline Austria & 100 & 1 & 23 \\
\hline Azerbaijan & 94 & 92 & -11 \\
\hline Bahamas & 100 & 1 & 35 \\
\hline Bahrain & 100 & 1 & 12 \\
\hline Bangladesh & 99 & 34 & 97 \\
\hline Barbados & 89 & 139 & -94 \\
\hline Belarus & 93 & 106 & 44 \\
\hline Belgium & 98 & 48 & -13 \\
\hline Belize & 92 & 112 & 3 \\
\hline Benin & 94 & 92 & 21 \\
\hline Bhutan & 89 & 139 & -23 \\
\hline Bolivia & 90 & 134 & 24 \\
\hline Bosnia and Herzegovina & 97 & 66 & 35 \\
\hline Botswana & 92 & 112 & -85 \\
\hline Brazil & 82 & 169 & -55 \\
\hline Bulgaria & 98 & 48 & 13 \\
\hline Burkina Faso & 93 & 106 & -8 \\
\hline Burma & 97 & 66 & 96 \\
\hline Burundi & 82 & 169 & -28 \\
\hline Cambodia & 98 & 48 & 60 \\
\hline Cameroon & 92 & 112 & 24 \\
\hline Canada & 99 & 34 & -28 \\
\hline Cape Verde & 93 & 106 & -46 \\
\hline Central African Republic & 99 & 34 & 127 \\
\hline Chad & 87 & 151 & 16 \\
\hline Chile & 100 & 1 & 6 \\
\hline China & 91 & 126 & 11 \\
\hline
\end{tabular}




\begin{tabular}{|c|c|c|c|}
\hline \multirow{3}{*}{$\begin{array}{l}\text { Colombia } \\
\text { Comoros } \\
\text { Congo, Democratic Republic of the } \\
\text { Congo }\end{array}$} & 94 & 92 & -58 \\
\hline & 93 & 106 & 36 \\
\hline & 81 & 173 & -1 \\
\hline Congo, Republic of & 87 & 151 & 18 \\
\hline Costa Rica & 97 & 66 & -13 \\
\hline Côte d'Ivoire & 94 & 92 & 15 \\
\hline Croatia & 97 & 66 & 21 \\
\hline Cuba & 76 & 176 & 1 \\
\hline Cyprus & 94 & 92 & -46 \\
\hline Czech Republic & 98 & 48 & -22 \\
\hline Denmark & 100 & 1 & 9 \\
\hline Djibouti & 91 & 126 & -8 \\
\hline Dominica & 99 & 34 & 29 \\
\hline Dominican Republic & 100 & 1 & 79 \\
\hline Ecuador & 83 & 166 & -7 \\
\hline Egypt & 87 & 151 & -16 \\
\hline El Salvador & 96 & 75 & -16 \\
\hline Equatorial Guinea & 87 & 151 & 17 \\
\hline Eritrea & 77 & 174 & 0 \\
\hline Estonia & 99 & 34 & -23 \\
\hline Ethiopia & 96 & 75 & 76 \\
\hline Fiji & 89 & 139 & -40 \\
\hline Finland & 100 & 1 & 18 \\
\hline France & 92 & 112 & -42 \\
\hline Gabon & 90 & 134 & -29 \\
\hline Gambia & 87 & 151 & -59 \\
\hline Georgia & 98 & 48 & -26 \\
\hline Germany & 99 & 34 & -16 \\
\hline Ghana & 92 & 112 & -46 \\
\hline Greece & 92 & 112 & 7 \\
\hline Guatemala & 100 & 1 & 82 \\
\hline Guinea & 94 & 92 & 41 \\
\hline Guinea-Bissau & 95 & 81 & 62 \\
\hline Guyana & 92 & 112 & 9 \\
\hline Haiti & 87 & 151 & 5 \\
\hline Honduras & 91 & 126 & -14 \\
\hline Hong Kong SAR & 100 & 1 & 0 \\
\hline Hungary & 98 & 48 & 3 \\
\hline Iceland & 99 & 34 & -11 \\
\hline India & 86 & 163 & -43 \\
\hline Indonesia & 97 & 66 & 34 \\
\hline Iran & 93 & 106 & 67 \\
\hline Ireland & 100 & 1 & 8 \\
\hline Israel & 94 & 92 & -48 \\
\hline Italy & 98 & 48 & 38 \\
\hline Jamaica & 94 & 92 & -36 \\
\hline
\end{tabular}




\begin{tabular}{|c|c|c|c|}
\hline Japan & 100 & 1 & 24 \\
\hline Jordan & 98 & 48 & -9 \\
\hline Kazakhstan & 97 & 66 & 1 \\
\hline Kenya & 88 & 146 & -35 \\
\hline Kiribati & 94 & 92 & 72 \\
\hline Korea, North & 5 & 178 & 0 \\
\hline Korea, South & 96 & 75 & -44 \\
\hline Kuwait & 98 & 48 & 28 \\
\hline Kyrgyz Republic & 97 & 66 & 19 \\
\hline Lao P.D.R. & 95 & 81 & 63 \\
\hline Latvia & 98 & 48 & -6 \\
\hline Lebanon & 92 & 112 & -16 \\
\hline Lesotho & 87 & 151 & 3 \\
\hline Liberia & 86 & 163 & -25 \\
\hline Lithuania & 99 & 34 & -13 \\
\hline Luxembourg & 100 & 1 & 15 \\
\hline Macau & 100 & 1 & 28 \\
\hline Macedonia & 100 & 1 & 42 \\
\hline Madagascar & 100 & 1 & 78 \\
\hline Malawi & 82 & 169 & -45 \\
\hline Malaysia & 96 & 75 & -38 \\
\hline Maldives & 100 & 1 & 144 \\
\hline Mali & 91 & 126 & -4 \\
\hline Malta & 98 & 48 & 10 \\
\hline Mauritania & 89 & 139 & -5 \\
\hline Mauritius & 99 & 34 & -26 \\
\hline Mexico & 95 & 81 & -26 \\
\hline Micronesia & 98 & 48 & 105 \\
\hline Moldova & 91 & 126 & -16 \\
\hline Mongolia & 87 & 151 & -54 \\
\hline Montenegro & 96 & 75 & -7 \\
\hline Morocco & 92 & 112 & -9 \\
\hline Mozambique & 94 & 92 & 36 \\
\hline Namibia & 92 & 112 & -18 \\
\hline Nepal & 97 & 66 & 83 \\
\hline Netherlands & 100 & 1 & 14 \\
\hline New Zealand & 100 & 1 & 4 \\
\hline Nicaragua & 95 & 81 & 21 \\
\hline Niger & 100 & 1 & 126 \\
\hline Nigeria & 87 & 151 & -22 \\
\hline Norway & 99 & 34 & -2 \\
\hline Oman & 99 & 34 & 14 \\
\hline Pakistan & 95 & 81 & 45 \\
\hline Panama & 91 & 126 & -55 \\
\hline Papua New Guinea & 95 & 81 & 51 \\
\hline Paraguay & 100 & 1 & 77 \\
\hline
\end{tabular}




\begin{tabular}{|c|c|c|c|}
\hline Peru & 100 & 1 & 46 \\
\hline Philippines & 99 & 34 & 55 \\
\hline Poland & 98 & 48 & 2 \\
\hline Portugal & 98 & 48 & 21 \\
\hline Qatar & 100 & 1 & 29 \\
\hline Romania & 98 & 48 & 14 \\
\hline Russia & 88 & 146 & -6 \\
\hline Rwanda & 90 & 134 & -69 \\
\hline Saint. Lucia & 97 & 66 & -33 \\
\hline Saint. Vincent and the Grenadines & 94 & 92 & -40 \\
\hline Samoa & 90 & 134 & -50 \\
\hline São Tomé and Príncipe & 89 & 139 & 18 \\
\hline Saudi Arabia & 100 & 1 & 76 \\
\hline Senegal & 95 & 81 & 44 \\
\hline Serbia & 88 & 146 & -51 \\
\hline Seychelles & 88 & 146 & -29 \\
\hline Sierra Leone & 92 & 112 & 36 \\
\hline Singapore & 100 & 1 & 1 \\
\hline Slovak Republic & 98 & 48 & 9 \\
\hline Slovenia & 98 & 48 & 26 \\
\hline Solomon Islands & 87 & 151 & 14 \\
\hline South Africa & 89 & 139 & -64 \\
\hline Spain & 98 & 48 & 1 \\
\hline Sri Lanka & 94 & 92 & -2 \\
\hline Suriname & 87 & 151 & -21 \\
\hline Swaziland & 91 & 126 & -44 \\
\hline Sweden & 100 & 1 & 19 \\
\hline Switzerland & 100 & 1 & 3 \\
\hline Taiwan & 99 & 34 & -17 \\
\hline Tajikistan & 93 & 106 & 33 \\
\hline Tanzania & 86 & 163 & -57 \\
\hline Thailand & 91 & 126 & -54 \\
\hline Timor-Leste & 83 & 166 & 4 \\
\hline Togo & 92 & 112 & 40 \\
\hline Tonga & 95 & 81 & 23 \\
\hline Trinidad and Tobago & 89 & 139 & -66 \\
\hline Tunisia & 90 & 134 & -25 \\
\hline Turkey & 94 & 92 & -28 \\
\hline Turkmenistan & 100 & 1 & 170 \\
\hline Uganda & 95 & 81 & 10 \\
\hline Ukraine & 96 & 75 & 80 \\
\hline United Arab Emirates & 100 & 1 & 27 \\
\hline United Kingdom & 100 & 1 & 13 \\
\hline United States & 100 & 1 & 11 \\
\hline Uruguay & 92 & 112 & -74 \\
\hline Uzbekistan & 92 & 112 & 51 \\
\hline
\end{tabular}


Vanuatu

Venezuela

Vietnam

Yemen

Zambia

Zimbabwe

Brunei Darussalam

\begin{tabular}{rrr}
100 & 1 & 92 \\
76 & 176 & -1 \\
87 & 151 & -4 \\
95 & 81 & 42 \\
94 & 92 & -4 \\
83 & 166 & 10 \\
100 & 1 & 39 \\
\hline
\end{tabular}

